\title{
CULTURAS DO PASSADO-PRESENTE: UM ESTUDO SOBRE O DISCURSO DA NOVIDADE E AS POLÍTICAS PATRIMONIAIS EM UM RECIFE DE TRÊS TEMPOS
}

\section{- FRANCISCO SÁ BARRETO}

http:/ /orcid.org/0000-0001-6659-7047

Universidade Federal de Pernambuco

\section{IZABELLA MEDEIROS}

https://orcid.org/0000-0003-0452-7734

Universidade Federal de Pernambuco

O presente artigo tenta compreender de que maneiras, em eventos temporais específicos, familiaridades e estranhamentos constroem formas e agendas políticas de modernização e ruptura, desenvolvimento e reflexão sobre as políticas de cidade e as dinâmicas para projeção da vida urbana. Dessa forma, nosso objetivo foi investigar como uma cultura do passado-presente emerge enquanto linguagem política por meio dos discursos sobre a novidade (modernidade, progresso, desenvolvimento) e identidade (tradição, memória, patrimônio) em um Recife de três tempos, momentos da história recente de Recife, que dizem respeito a importantes programas de intervenção político-urbanístico-patrimonial na cidade. Para isso, realizamos pesquisa bibliográfica e documental a fim de construir os dados que nos levassem à construção analítica de nosso objeto.

Palavras-chave: Modernidade. Tradição. Políticas patrimoniais. Urbanização. Cultura política.

\section{ABSTRACT \\ PAST-PRESENT CULTURE: A STUDY ON DISCUSS ABOUT MODERNITY AND THE HERITAGE POLICIES AT RECIFE IN THREE DIFFERENT TIMES}

This paper aims to understand how, in some specifics events in time, familiarities and strangeness could be built shapes and political agendas for modernization or ruptures in a contemporary city. In this way, our main point was to investigate how a past-present culture arises as a political language in some discuss on modernity (novelty, progress, development) and tradition (identity, memory, cultural 
heritage), taking the Brazilian city Recife as a model in three different moments of its History, which means important events for big political, urbanist and cultural projection of this city. For it, we did a documental research to built some data for thinking about our research subject.

Keywords: Modernity. Tradition. Heritage policies. Urbanization. Political culture.

\section{RESUMEN CULTURAS DEL PASADO-PRESENTE: UN ESTUDIO SOBRE EL DISCURSO DE LA NOVEDAD Y LAS POLÍTICAS PATRIMONIALES EN UNA RECIFE DE TRES TIEMPOS}

El presente artículo intenta comprender cómo, en eventos temporales específicos, las familiaridades y extrañezas construyen formas y agendas políticas de modernización y ruptura, desarrollo y reflexión sobre las políticas y dinámicas de la ciudad para la proyección de la vida urbana. Por lo tanto, nuestro objetivo fue investigar cómo una cultura del pasado-presente emerge como un lenguaje político a través de discursos acerca de la novedad (modernidad, progreso, desarrollo) y la identidad (tradición, memoria, patrimonio) en un Recife de tres tiempos distintos, momentos de la historia reciente de Recife, que se relacionan con importantes programas de intervención político-urbanístico-patrimonial en la ciudad. Para esto, llevamos a cabo una investigación bibliográfica y documental para construir los datos que nos llevarían a la construcción analítica de nuestro objeto. Palabras clave: Modernidad. Tradición. Políticas patrimoniales. Urbanización. Cultura política.

\section{Postulando um problema}

$\mathrm{Na}$ história recente das grandes cidades do globo, o complexo paradoxo do mergulho profundo da sedução pelo novo e o desejo permanente de manter raízes bem saudáveis sobre uma política sempre atual da tradição têm se constituído como movimento bastante recorrente. Nesse cenário, parece cada vez mais claro que as questões concernentes ao conceito e às expressões de cultura estão fortemente vinculadas às dificeis compreensões das formas políticas contemporâneas e seus rebatimentos nos projetos de cidade e modelo de sociedade traduzido pela vida e pelo consumo coletivos urbanos. Entender como essas dinâmicas se processam na cidade de Recife por meio das narrativas em torno do patrimônio urbano é o objeto deste trabalho.

Para isso, escolhemos três recortes da história recente do projeto de modernização da cidade. O primeiro retoma o fim dos anos 1930 e o início dos anos 1940, quando da construção de uma Avenida Guararapes muito próxima de como a conhecemos em dias atuais, peça central para forte intervenção urbana não somente no centro da capital pernambucana como no imaginário de modernidade e tradição da po- 
pulação recifense. 0 segundo recorte nos leva aos anos 1970, inauguração da Avenida Dantas Barreto, também no centro de Recife e palco para reprodução de discursos que tinham nosso paradoxo-problema como pauta fundamental: um mergulho entorpecido em um programa de novidade vestido de tradição. 0 terceiro recorte refere-se aos anos 2000, momento em que o projeto municipal para requalificação urbana de parte das regiões do centro da cidade, denominado de "Projeto Novo Recife", começou a ser realizado. Um grande volume de matérias de jornal - impresso, on-line ou televisivo - apresentava como "novidade", "modernidade", "desenvolvimento" e "progresso" boa parte dos significados mobilizados e das mudanças que iriam acontecer pelo Projeto Novo Recife. Um conjunto de ocupações, por meio do movimento que ficou conhecido como Ocupe Estelita, funcionou como mecanismos para resistência que tiveram o projeto em questão apenas como mote. 0 que se seguiu aos levantes e à montagem e ao uso do acampamento que se instalou por aproximadamente 50 dias foi uma série de atividades que procuraram refletir sobre críticas e alternativas ao projeto de cidade como um todo.

Nesse Recife de três tempos, pode-se ver bem constituído um importante enclave para compreensão das formas políticas do contemporâneo e sua tradução no projeto de social bem consolidado nas grandes cidades: a emergência de uma forte cultura do passado que não pode sobreviver sem a construção de uma vigorosa mercantilização do futuro. É o que poderíamos projetar a partir de usos estratégicos da maquinaria patrimonial como importante recurso para um mercado do turismo global. Assim, dessa complexa relação entre tempos e durações, nossa intenção é compreender de que maneiras emerge uma cultura do passado -presente como linguagem política por meio dos discursos sobre a novidade (modernida- de, progresso, desenvolvimento) e identidade (tradição, memória, patrimônio) em três recortes específicos da história recente de Recife.

Os três recortes escolhidos para o desenvolvimento desta investigação justificam-se a partir de, ao mesmo tempo, forte filiação e afastamento. Em primeiro lugar, procuramos "zonear" a análise na cidade de Recife em sua região central - bairros de Santo Antônio e São José. Ambos passaram por intensas modificações ao longo do século XX e - ainda se projeta - no primeiro quartel do século XXI. Nos três casos, as razões para as intervenções se aproximam bastante e estão divididas em dois eixos fundamentais: por um lado, modernizar a paisagem urbana e, por outro, otimizar o trânsito e estimular o comércio na região. No caso específico da zona de galpões da antiga empresa da Rede Ferroviária Federal (RFFSA) do Cais José Estelita, traduzem-se também no projeto as atualizações dos programas de "requalificação" urbana - gentrificação (PROENÇA LEITE, 2007) em sua compreensão mais estrita - e forte especulação imobiliária. O elemento discursivo comum é, contudo, o dispositivo da novidade materializada na modernização.

Em fins dos anos 1930, esse movimento acompanha uma das grandes ondas de modernização nas grandes cidades brasileiras - muitos autores apresentariam como a maior onda. Trata-se de um período de intensa industrialização e consolidação do que poderíamos apontar como o modelo estado-novista de desenvolvimento econômico e social. Se a Recife colonial de espaços públicos predominantemente vazios começara a ser "abandonada" 40 anos antes, a abertura de grandes avenidas e instalação de grandes edificios no centro da cidade funcionariam como sinais de, por um lado, crescimento econômico e, por outro, agitação cultural e disposição para o cosmopolitismo. Esse movimento, no entanto, rebatido por um sem-número de fortes críticas predo- 
minantemente referentes à demolição do antigo casario da região - de pretenso grande valor patrimonial - precisou ser acompanhado por um discurso que tinha como sujeito uma cidade do passado que clama pela modernização; a tradição que se consolidaria no abraço à novidade.

Já nos anos 1970, quando da abertura da Avenida Dantas Barreto, os efeitos sobre a maquinaria patrimonial da cidade mobilizaram maior atuação da população contra o projeto. Além disso, instituições de proteção ao patrimônio, como o Instituto do Patrimônio Histórico e Artístico Nacional (Iphan), por exemplo já atuavam reforçando as lógicas de conservação do lugar como instrumento de produção de sentidos para a cidade. 0 projeto de alargamento das antigas ruas da região, ligando o centro da cidade às entradas de sua região sul, foi, contudo, levado adiante de forma bastante impopular, mas não o suficiente para frear o programa desenvolvimentista do prefeito $\mathrm{Au}$ gusto Lucena. 0 fruto de sua decisão, por fim, se integrou ao projeto de cidade. Sua constituição como patrimônio da cidade funcionou como recurso fundamental para a consolidação da intervenção como forma política da cidade que se desenvolvia. Mais uma vez, tradição e modernidade se encontram no abraço de um discurso que carrega um apelo forte, ao mesmo tempo, a uma política das identidades e ao desenvolvimentismo. Nesse recorte, em específico, um discurso sobre a necessidade de estimular a cultura como objeto da política já podia ser destacado como importante face do projeto de cidade que se queria desenvolver. A conversão da antiga Casa de Detenção do Recife em um pavilhão que reunisse traços fundamentais da cultura pernambucana (Casa da Cultura) é um bom exemplo disso. Via-se, desde ali, uma compreensão política da cultura fortemente alinhada com as demandas de um novo mercado do turismo, por um lado, e de uma política de higienismo para o centro da cidade, por outro.

A partir da década de 1990, as gestões da prefeitura da cidade do Recife investiram pesado em uma política de revitalização de tradicionais centros históricos então já praticada em outras cidades do mundo. A ação acompanhava a tendência de intervenções à época já realizadas na região do Pelourinho, em Salvador, por exemplo. Em Recife, as ações deram conta, inicialmente, de reforma da Rua do Bom Jesus, no bairro do Recife, com nova pintura do casario e instalação de bares, restaurantes e boates, além do forte apelo turístico-religioso - patrimonial com a revitalização da Sinagoga Kahal Zur Israel, a mais antiga das Américas. A política em questão substituiu os tons ocres característicos do início do século XX por cores fortes, em sintonia com gestões fortemente pautadas naquilo que Del Castillo (2008) chamou de "Disneylandização" da memória e do patrimônio para marcar a forte aproximação de ambos com um tipo de turismo erguido sobre a lógica do entretenimento. Os antigos centros de grandes cidades brasileiras deveriam ter, portanto, sua política de revitalização centrada em forte apelo turístico, transformando-se, preferencialmente, em zonas de entretenimento e consumo de bens culturais das cidades em questão.

Vivendo grandes altos e baixos, tal empreendimento político em Recife foi finalmente retomado a partir da segunda metade da década de 2000, notadamente a partir de 2010, com a reforma do terminal náutico de passageiros e a instalação de centros de artesanato e dois museus fortemente vinculados a políticas de entretenimento - o Museu Cais do Sertão e o Paço do Frevo. A expansão desse programa tem na região do Cais José Estelita o programa de sua nova etapa, cumprindo importante agenda de expansão da especulação imobiliária na cidade, com intenção de 
construção de 12 grandes torres empresariais/ residenciais, pretensamente estimulando 0 comércio e a circulação de pessoas na antiga região de galpões da RFFSA. Acrescenta-se ao projeto de cidade o suplício da diferença como parte constitutiva das políticas de cultura para a cidade que se esboça ainda na primeira metade do século XXI.

Nos três recortes escolhidos, observamos a emergência de um debate sobre questões que envolvem políticas da tradição e identidade, cruzadas por um discurso de progresso e de novidade. Percebemos, nessa familiaridade, a construção de uma cultura de constituição do passado como sofisticado produto para justificação do discurso do novo, linguagem política do contemporâneo por excelência, a partir da qual o consumo do passado enquanto cultura do presente orienta um forte mercado das identidades/patrimônios/memórias como sofisticado e dissimulado empreendimento político do contemporâneo. Nas páginas que seguem, procuramos, então, observar o funcionamento dessa lógica em cada um dos recortes a fim de sugerir um projeto de cidade em construção em Recife há, pelo menos, 80 anos. Assim, procuramos desenvolver nossa discussão pautada em três temas geradores: a) Cidade, nação e desenvolvimento; b) Cultura e desenvolvimento urbano; e c) Gentrificação e resistências.

\section{Cidade, nação e desenvolvimento}

Eu por mim já me sinto um tanto estrangeiro no Recife de agora. 0 meu Recife era outro. Tinha um 'sujo de velhice' que me impressionava, com um místico prestígio, a meninice [...]. Resignemo-nos os que ainda nascemos no tempo da Lingüeta, do Arco de Santo Antônio e dos cocheiros de cartola, à melancolia desse destino: o de acabarmos estrangeiros na própria cidade natal. Eu por mim já me sinto um tanto estrangeiro. (FREYRE, Diário de Pernambuco, 20/4/1924).
Estou de consciência tranquila pela certeza de que venho envidando todos os esforços em prol dos supremos interesses da cidade do Recife. Em menos de dois anos de administração, o governo municipal pode apresentar, sem vaidades e sem exhibicionismo, um eschema de realizações que conforta e tranquiliza. Posso recordá -lo, isento de ostentação e vangloria, porque o trabalho que vimos realizando foge, rigorosamente, aos quadros do esforço pessoal: é fruto do regimen de trabalho e acção administrativa que o Estado Novo, em boa hora, veiu inaugurar para a salvação do país (Prefeito Novais Filho, Folha da Manhã, 31/08/1939).

Seja no Guia prático, histórico e sentimental da cidade do Recife (1934), seja em não poucos textos publicados em jornais da época, o tom de Gilberto Freyre ao falar da cidade natal, quando de seu retorno depois de relativamente longa passagem nos Estados unidos da América (EUA), era de desânimo e nostalgia (VERAS, 2014). A cidade tinha vivido intensas transformações em suas regiões de centro, modificado características e, fundamentalmente, havia crescido. A narrativa de "saudade de bons tempos" representa a fenda aberta entre duas cidades, aparentemente, distintas. De um lado, a cidade que deixara anos antes, com lugares bem definidos por um conjunto de sentidos bem colocados do urbano. De outro lado - insiste a narrativa do autor -, outra cidade, entorpecida pelo desenvolvimento e pelo suposto aprofundamento de cisões entre tempos: um passado abandonado e um abraço acalorado no futuro/novidade.

A narrativa de Freyre encontra um sem-fim de lugares comuns à oposição entre desenvolvimento e tradição na descrição da cidade. É certamente difícil compreendê-la no contexto da emocionalidade que fundamenta um tipo teórico-metodológico para interpretação das dinâmicas políticas do país para tal autor. Entre a casa-grande e a senzala, entre os sobrados e mocambos, há linhas de divisão mais poderosas que aquelas costumeiramente desenhadas 
por uma cisão entre ricos e pobres, opressores e oprimidos. Se, nos anos 1930, o mesmo Freyre apresentava como narrativa da nação uma dinâmica da miscigenação como característica estruturante da brasilidade, fazia-o investindo na tese de que as relações entre as diferentes matrizes étnicas da jovem República estavam estabelecidas por um sadomasoquismo simbiótico entre europeus, africanos e indígenas. Sobrados e mocambos representavam essa dinâmica no contexto da sociedade urbana em desenvolvimento no país.

0 estranhamento de Freyre era pouco compativel com o desenho de cidade que se desenvolvia, fortemente pautado em processos de marginalização - em seu sentido mais prosaico - de grupos mais pobres e na escritura de um programa de novidade também alinhado a uma experiência de "sempre existência" da tradição - ainda que isso efetivamente também fosse novo.

No final dos anos 1930, com a emergência do Estado Novo, Pernambuco tinha governador e prefeito interventores, Agamenon MagaIhães e Novais Filho, respectivamente. Ambos representavam um complexo cruzamento da política dos coronéis alinhada a forte discurso nacionalista. O programa de nação nesse contexto não pode ser mais do que uma espécie de Estado de confraria que traduziu seu projeto de nacionalidade num complexo empreendimento para inclusão excludente na brasilidade (SOUZA, 2006). Casa Grande \& Senzala, publicado poucos anos antes (1933), reforçaria a tese de unidade em torno do projeto nacional como resultado de uma democracia racial pautada na junção de três "raças". A cidade, obviamente, materializaria esse empreendimento.

Ainda que, em 1939, os mocambos representassem $67 \%$ das edificações da cidade de Recife (PONTUAL, 2001), eles nunca traduziram uma herança arquitetônico-urbanística. Pelo contrário, é bastante claro, como veremos adiante, que esse traço da ocupação do espaço e produção dos lugares urbanos representava uma cidade silenciosa que deveria desaparecer, visto que não seria compatível com o projeto nacional-desenvolvimentista em curso, notadamente a partir dos anos 1940.

Nesse contexto, o estranhamento de Freyre ao retornar dos EUA narra, ao observarmos de forma cuidadosa, a complexa passagem da sociedade erguida sobre o sadomasoquismo ruralista da experiência pré-republicana ao movimento insustentável do fenômeno da urbanização no país. A publicação, em 1936, de Sobrados e Mucambos, traduz analiticamente essa passagem, convertendo os pares coloniais de seu livro anterior em dispositivos possiveis para a sociedade urbana.

O grande desafio do Estado Novo em Recife, dessa forma, foi modernizar a cidade sem que isso representasse a superação das estruturas coloniais, sejam elas para administração da cidade, sejam para uma herança arquitetônica, ou sejam, as mesmas, para consolidar um projeto patrimonial que cruzaria, de forma complexa, desenvolvimento e tradição como marcas da cidade contemporânea.

Alguns elementos discursivos para esse empreendimento precisam ser observados, visto que estruturam ainda o projeto de administração da cidade em nossos dias. O primeiro deles é um esboço do que se configuraria de forma mais intensa nos anos 1970 e ditaria a norma política contemporânea para cidade nos anos 2010: o paradigma da gestão eficiente. Já no final dos anos 1930, contudo, podemos dizer que "[...] trabalhar pela prosperidade e manter as tradições foram duas metas perseguidas por Agamenon e seu séquito político, por meio de três principais linhas de ação: os centros operários, a campanha contra os mocambos e a política agrícola" (PONTUAL, 2001, p. 69). As três linhas da "gestão eficiente" 
empreenderiam: a) a doutrinação católica contra os movimentos operários de referência comunista, procurando eliminar o inimigo interno do projeto "contranacional", característico do Estado de polícia republicano (SÁ BARRETO, 2012); b) empurrar para novas bordas urbanas os grupos mais pobres da cidade, marcando, com grandes deslocamentos populacionais, lógicas de distribuição do espaço extremamente desiguais, típicas de empreendimentos higienistas (SEVCENKO, 2010); e c) conservar, a partir de complexa atualização, o governo dos coronéis, convertidos, por sua vez, em “doutores" nos sobrados ou, décadas adiante, nas coberturas de altíssimas torres da Recife hodierna. Elementos para esse discurso estão presentes mesmo na fala de Agamenon Magalhães, quando da nomeação de Novais Filho, como podemos ver no seguinte fragmento de um texto jornalístico:

Quando nomeei um agricultor Prefeito do Recife, o meu acto foi recebido com reservas e críticas até de amigos meus [...]. 0 meu acto, nomeando um homem do campo, administrador honesto dos seus bens e apaixonado pela terra e os problemas econômicos de Pernambuco, obedeceu aos imperativos da política social, que seria a base do meu plano de governo. (FoIha da Manhã, 31/08/1938)

Um novo sentido para a política brasileira refletida nas cidades, ainda na década de 1930, estaria traduzido em governos extremamente conservadores comprometidos com o desenvolvimento de dispositivos que serviam à atualização das estruturas sociais coloniais para uma experiência republicana de cidade. O paradigma da gestão eficiente seria uma importante ferramenta para a confusão entre nação e governo, tão necessária à política do Estado Novo para as cidades. Essa fusão simplifica complexos produtos: o movimento operário e o mocambo são inimigos da cidade e a superação deles significaria modernização, desenvolvimento e, fundamentalmente, nacionalismo (tradição). As intervenções no urbano, dessa forma, deveriam possibilitar, ao mesmo tempo, combater as ameaças desse "inimigo interno" e estimular o escoamento da produção agrícola, movimento que em muito remete ao projeto higienista de Rodrigues Alves (19021906) e do governo de Pereira Passos no Rio de Janeiro da Revolta da Vacina. Mas não somente. Remete aos discursos contemporâneos para construção do propalado "Novo Recife", orientado para um futuro pautado em uma agenda de crescimento econômico, turismo global, monumentalismo e gentrificação. Efetivamente, os movimentos são bastante familiares.

Um segundo elemento discursivo igualmente potente e útil ao governo da cidade em fins dos anos 1930 e boa parte dos anos 1940 é aquilo que poderíamos chamar de discurso da razão monumental, ou seja, a lógica que mobiliza o conjunto de intervenções sobre vias e lugares públicos e seus desdobramentos sobre o projeto de cidade. Ainda em nosso projeto de pesquisa, concentramos esse recorte na abertura da Avenida Guararapes - então Avenida 10 de Novembro, por ocasião do Estado Novo. Essa intervenção, contudo, apenas resume, enquanto dispositivo paradigmático, uma série de modificações.

Em fins do século XIX e durante o primeiro conjunto de grandes intervenções no Bairro do Recife (anos 1910), podemos observar um processo que se desenvolveria de forma mais avassaladora a partir dos anos 1930: a substituição do que poderíamos chamar de "urbanismo religioso" de uma Recife "pré-moderna" por uma outra estrutura de consagração para os sentidos de público de uma nova cidade. De fato, a Igreja foi deixando de ser centro da vida pública na cidade sem que, para isso, suas lógicas de interdição a partir da moral e das regras públicas precisassem deixar de existir. Assim, os discursos do interventor ou do prefei- 
to, entre 1937 e 1945, puderam conservar forte teor para doutrinação católica conservadora, ainda que suas políticas de intervenção na cidade precisassem substituir igrejas ou pátios de hábitos culturais fortemente ligados ao elemento religioso.

A alternativa a esse movimento foi acompanhar a tendência de grandes cidades europeias, ou mesmo brasileiras: o espírito monumental do urbanismo hausmanniano (HUYSSEN, 2000), estendido para além do Bairro do Recife, que já vivera essa tendência 20 anos antes. Esse movimento deveria superar a planta tentacular da cidade do Recife, empurrando a população para novas zonas de ocupação da cidade e distribuindo, pelas regiões dos bairros de Santo Antônio e São José (centro), obras

Figura 1 - Planta do Recife, 1932.

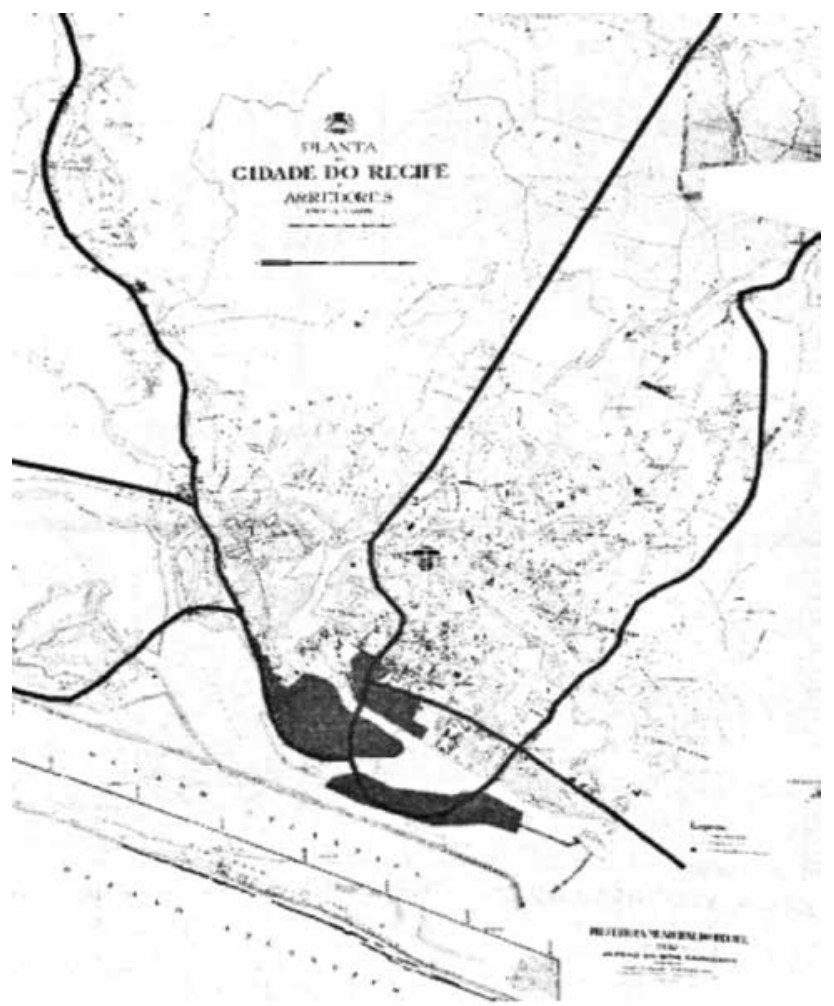

Fonte: Museu da Cidade de Recife.

1 A partir do Bairro do Recife, a cidade se distribuía pelo espaço, seguindo linhas tentaculares para as regiões Sul (Boa Viagem, Imbiribeira), Sudoeste (Afogados), Oeste (Madalena e Várzea), Noroeste (Casa Amarela) e Norte (Encruzilhada e Beberibe). que traduziriam a cidade enquanto monumento a si mesma: avenidas, pontes e parques. A elaboração de concursos de projetos arquitetônicos para a construção da Ponte Duarte Coelho - que ligaria a antiga Rua Formosa (atual Conde da Boa Vista) à novíssima Avenida 10 de Novembro (atual Avenida Guararapes) é apenas um pequeno exemplo do empreendimento: envolver a população em uma face positiva de grande conjunto de intervenções que celebrariam a própria cidade, ainda que isso deixasse em segundo plano um complexo processo de relocação de grupos pobres da cidade para regiões afastadas do centro (periferização). É o que pode ser observado nas Figuras 1 (mancha urbana de Recife em 1932) e 2 (mancha urbana de Recife em 1943):

Figura 2 - Planta do Recife, 1943.

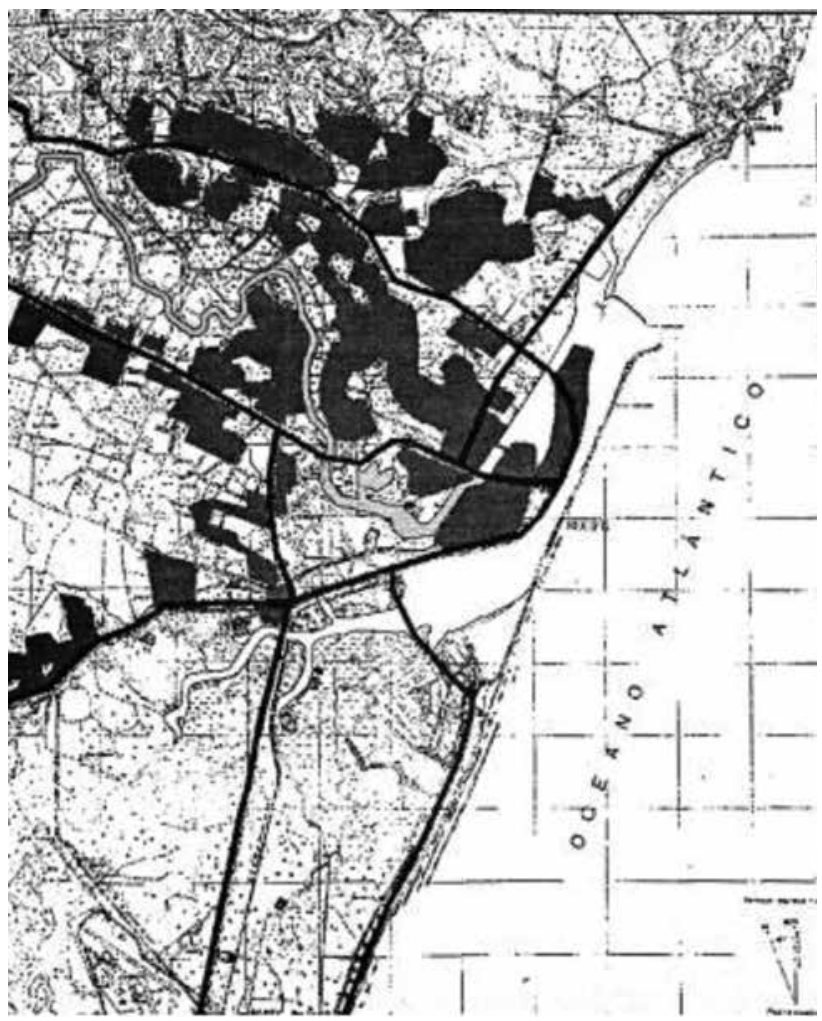

Claro que o aumento populacional é uma importante variável, ${ }^{2}$ mas, nesse caso, insuficiente para explicar as lógicas de ocupação do

2 Recife passou, nos anos 1920, de 238 mil habitantes a 348 mil, nos anos 1940. 
espaço na cidade. Nos bairros do centro, essas intervenções deveriam significar a abertura para circulação de automóveis e conexão de antigas ruas, antes ligadas por vielas estreitas e insalubres. Esse é exatamente o caso da Avenida 10 de Novembro, que deveria ligar a Praça da Independência à Praça Duarte Coelho a qual, por sua vez, daria lugar à ponte de mesmo nome. A ideia não era somente desafogar ruas menores, como a 1ㅇ de março ou Sigismundo Gonçalves, mas produzir a abertura como veia monumental do desenvolvimento urbano na Recife dos anos 1940.

As ideias constantes desses planos previam um futuro citadino eficiente aliado ao gosto estético, evocavam o progresso construtivo da cidade de modo a modificar a composição colonial vigente, e referenciavam a ordenação citadina segundo os preceitos do urbanismo moderno nas noções de embelezamento, higiene, salubridade e monumentalidade (PONTUAL, 2001, p. 87).

Não por acaso, boa parte dos principais nomes da gestão pública da cidade naqueles anos era ligada ao urbanismo. Se, na Berlim nazista, a maquete da cidade monumental de Albert Speer já seria suficiente para o projeto do nacionalismo alemão (HUYSSEN, 2000), a Recife, que toma o mesmo empreendimento de forma tão familiar em nossos dias, já o fazia há muito tempo, como podemos observar na novíssima Av. Guararapes, convertida em cartão postal da cidade no início dos anos 1950 (figura 3).

Figura 3 - Postal da Avenida Guararapes, anos 1950.

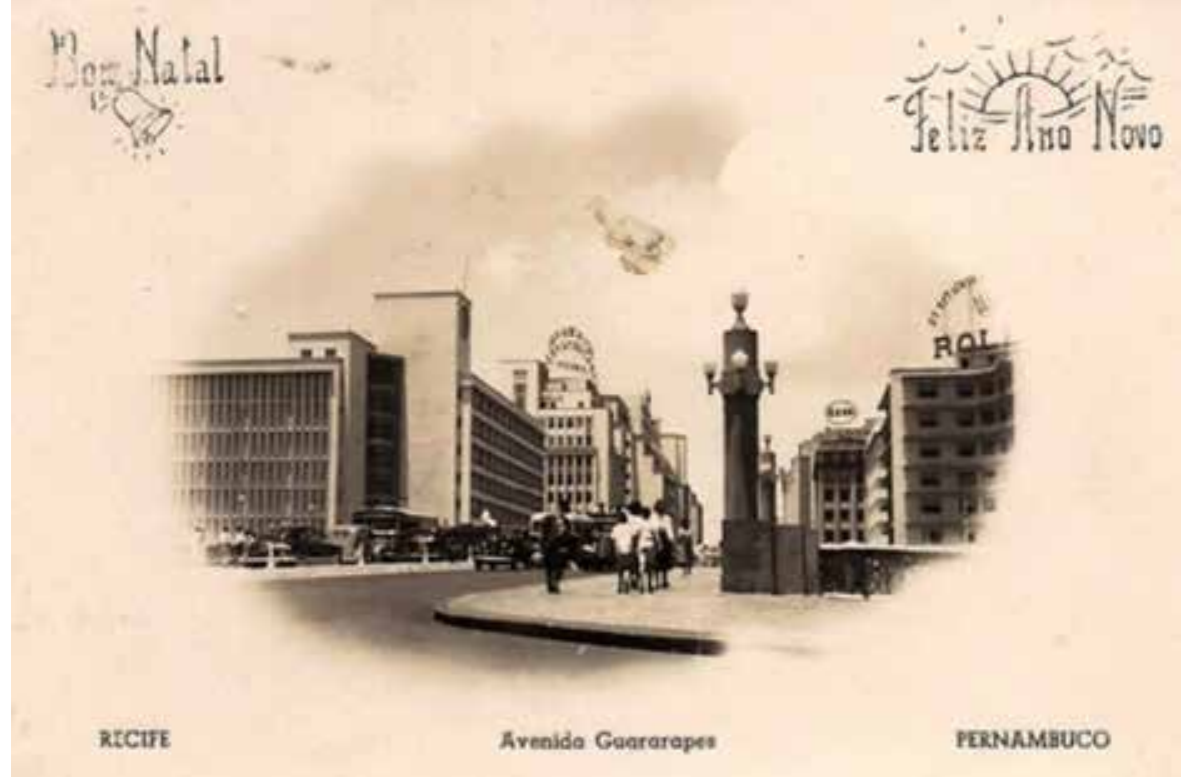

Fonte: Museu da Cidade de Recife.

Esse espírito de celebração, contudo, era fortemente acompanhando por um discurso alarmista que também estrutura o monumentalismo: o discurso da Liga Social Contra o Mocambo. A partir dele, qualquer traço de pobreza na cidade não podia representar elementos da cultura de Recife, mas exclusivamente sua degradação. Certamente não era difícil convencer boa parte da população desse discurso, visto que, assim como ocorre em nossos dias, os mocambos eram permanentemente ligados unicamente à degradação social e pobreza extrema. Os costumes populares, estratégias para vida e consumo coletivos, além daquilo que alguns poderiam chamar de sua arquitetura espontânea, não eram sequer elementos menores para o plano de reforma da cidade e sua regulação urbanística. 
As intervenções nos bairros de centro e a construção de habitações populares - medidas, por certo, populistas - implicaram intenso deslocamento populacional, já descrito nas Figuras 1 e 2. Não por acaso, nos primeiros anos da década de 1940, a diretoria responsável pela gestão das ações da Liga Social Contra o Mocambo era também responsável pela gestão de crimes e delitos urbanos: Diretoria de Reeducação e Assistência Social.

As medidas tomadas por Novais Filho estimularam ao extremo a construção civil na cidade, acelerando a verticalização e exigindo uma série de atualizações das legislações referentes a gabarito, mobilidade, circulação nas vias etc. A imponência das intervenções, aliada a discursos fortemente pautados no nacionalismo e positivismo estadonovista, produziam uma razão autoritária para gestão da cidade à qual era impossivel fazer oposição.

Nas periferias, a atuação da prefeitura foi no sentido de viabilizar as novas moradias e as migrações pendulares; a população deveria ter condições mínimas para transitar das zonas periféricas ao centro diariamente. Por isso, a ampliação dos serviços de transporte e a abertura de novas avenidas e pontes também podem ser verificadas nas regiões tentaculares da cidade.

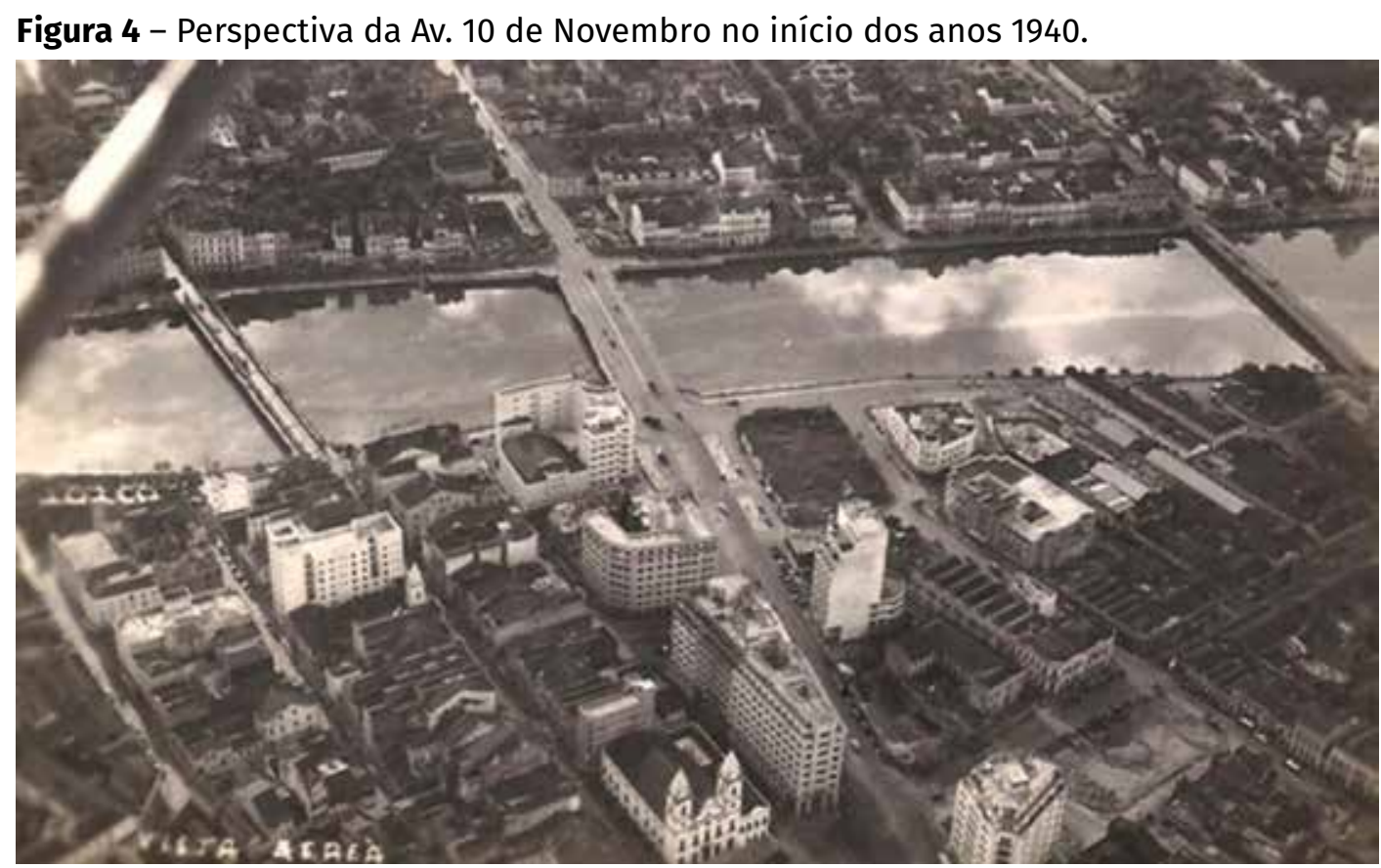

Fonte: Museu da Cidade de Recife.

Entre 1937 e 1945, período da gestão municipal de Novais Filho, os discursos da tradição e do desenvolvimento andaram fortemente acompanhados. Havia, desde ali, um complexo mecanismo para construção de uma cultura política do passado-presente estruturando o programa de cidade que seria desenvolvido nos anos que se seguiram. É o que podemos verificar nos dois outros recortes em discussão: as décadas de 1970 e 2010.

\section{Cultura e desenvolvimento}

\section{urbano}

Art. 950: Em todo edificio que vier a ser construído no Município do Recife, deverão constar obras originais de valor artístico, as quais farão parte integrante deles.

$\S 10$ Os efeitos do artigo anterior incidirão sobre:

I - todos os prédios com área superior a $2.000 \mathrm{~m}^{2}$ (dois mil metros quadrados) e bem assim os de grande concentração pública, tais como; ca- 
sas de Espetáculos, Hospitais, Casas de Saúde, Colégios ou Escolas Públicas, Estações de Passageiros, Estabelecimentos Bancários, Hotéis, Estádios, Clubes Esportivos, Sociais ou Recreativos que tenham áreas superior a $1.000 \mathrm{~m}^{2}(\mathrm{mil}$ metros quadrados).

$\S 2$ o Ficam isentos dos efeitos deste artigo as residências particulares.

§ 3ํNão será concedido à construção o competente Habite-se quando na mesma não constar a obra de arte exigida neste Código, cuja maquete deverá ser aprovada pela Prefeitura Municipal do Recife, com o visto do Autor do Projeto da Arquitetura, do Proprietário e assinatura do autor da Obra de Arte.

§ 4으 Somente poderão executar os serviços referidos no parágrafo anterior os artistas previamente inscritos na Prefeitura Municipal do Recife. (Lei Ordinária, no 7427, de 19/10/1961)

É dificil pensar um replanejamento das grandes cidades dos países do Ocidente do globo depois da Segunda Guerra Mundial sem que isso seja efetivamente atravessado por um debate sobre uma necessária relação entre Estado (gestão) e Cultura. 0 ápice do projeto nacionalista do século XIX conduziu as grandes nações do mundo a um choque sem precedentes nas duas grandes guerras do século XX. Um primeiro empreendimento humanista tinha sido arrasado pelo imperativo da pureza racial nazista e exigiu das novas políticas do pós-guerra um conjunto de revisões a fim de que a diversidade cultural se convertesse em objeto da experiência democrática.

Não por acaso, instituições concentradas no registro e na valorização das culturas diversas foram criadas ou receberam grandes investimentos imediatamente após o fim das guerras. É o caso, como emblemático exemplo, da Organização das Nações Unidas para Educação, Ciência e Cultura (Unesco) e do Conselho Internacional de Museus (Icom), ambos criados ainda em 1946 com a intenção de profissionalizar a gestão da diferença cultural (PEIXOTO, 2004).
A organização dos movimentos de contracultura e a elaboração de políticas de reconhecimento das diferenças são outros importantes sinais de que a conexão entre política e cultura exigiria novos comportamentos da gestão do Estado (HUYSSEN, 2000; HALL, 2003; ŽIŽEK, 2005). Esse imperativo seria montado para atender a duas demandas estruturais: a) administrar as insatisfações ligadas à injusta distribuição de capital nos ditos países desenvolvidos, refletidas, por sua vez, em zoneamentos culturais nas crescentes metrópoles; e b) reforçar políticas de compensação pela cultura, fortemente vigentes até os nossos dias. Como resultado direto do primeiro eixo, seria possivel falar em um sofisticado dispositivo disciplinar que se utiliza da memória cultural como recurso para a ordem pública. 0 produto imediato do segundo eixo estaria configurado nas políticas de financiamento cultural, responsáveis por alinhar os interesses dos gestores com o produto cultural das organizações -produtores-objetos das políticas culturais (YÚDICE, 2004).

O estímulo a uma política das imigrações ou da incorporação de imigrantes ilegais ao projeto nacional dos países de Primeiro Mundo não ocupa lugar menor nesse empreendimento. A partir de 1948, jamaicanos, iranianos, indianos, turcos, senegaleses, argelinos, camaroneses, nigerianos, sul-africanos, mexicanos, porto-riquenhos, guatemaltecos, cubanos e tantos outros foram convertidos em complexo objeto das políticas adesionistas de reconhecimento que pautaram as compensações do poder colonial das renovadas metrópoles (SÁ BARRETO, 2012). Esses esforços, não parece dificil inferir, representaram sofisticados programas de periferização das grandes cidades europeias e dos EUA, fazendo ser mais dificil o enquadramento de grandes zonas cegas urbanas (MONTALDO, 2010; SARLO, 2005) ao escorregadio conceito de gueto em Wacquant (2008) 
como um paradigma das grandes cidades contemporâneas. Os programas para gestão dos conflitos decorrentes das políticas de reconhecimento não deixaram de configurar-se enquanto programas de gestão cultural.

Somando-se a isso, e em um lugar não menos importante nessa discussão, crises econômicas cíclicas a partir dos anos 1960 despertaram grande interesse de Estados e corporações na/para exploração da mercadoria cultural, propriamente dita. Um boom de museus (HUYSSEN, 2001), incluindo redes de franquias museais (YÚDICE, 2004) - como no caso do Guggenheim - ao redor do globo explica apenas parte do processo; diz respeito a um complexo mercado do turismo global, em vertiginoso desenvolvimento notadamente a partir dos anos 1970, o qual produz reflexo direto sobre as formas e gestões urbanas contemporâneas. A partir dele, não representa qualquer exagero a observação de que arte e cultura converteram-se em complexos dispositivos de gestão do Estado, processo ainda mais aprofundado devido à queda do Muro de Berlim (1989) e a uma profissionalização dos registros de patrimônios mundiais materiais ou imateriais (Santos e PEIXOTO, 2013). Como exemplo, apenas mencionar que Paris recebe mais visitantes por ano do que todo o território brasileiro já demonstra a pujança de uma economia da cultura a serviço do turismo global. ${ }^{3} \mathrm{O}$ foco de nossa atenção, contudo, ainda não é esse.

A cultura como recurso (YÚDICE, 2004) não diz respeito somente à produção de divisas a partir da mercadoria cultural, o que, está claro, não é pouco. Versa sobre a cultura como dispositivo de gestão.

Nos discursos para um conjunto de intervenções nos bairros de centro em Recife no

3 Segundo a Organização Mundial do Turismo (OMT), Paris recebeu, em 2013, 15,5 milhões de turistas; o Brasil, por sua vez, segundo dados da mesma instituição, recebeu o número recorde de 6 milhões de turistas estrangeiros. final dos anos 1930 e durante os anos 1940, era possivel visualizar uma cultura do passado-presente (HUYSSEN, 2014) como estruturante de políticas desenvolvimentistas para a cidade. A narrativa identitária estava presente sob o formato de uma tese de cidade historicamente forte e tradicional, que precisava ser salva da degradação dos mocambos.

Os anos 1950 e início dos anos 1960, em Recife, ficaram marcados por gestões orientadas pelo socialismo de Pelópidas da Silveira - na prefeitura - e de Miguel Arraes - no governo do Estado. Ao longo daqueles anos, além de seguir a cartilha do nacional-desenvolvimentismo de Juscelino Kubitschek, era possivel observar forte tendência da gestão municipal - eventualmente populista - ao adesionismo do popular à narrativa da cidade. Não por acaso, Silveira foi recorrentemente acusado de passar por cima do poder legislativo, ao investir em câmaras de escuta direta da comunidade. Esses movimentos fizeram dele, contudo, um gestor benquisto pelas populações mais pobres e, visto que ainda era empreendedor de grandes obras, também aprovado pelos grupos de elite. A última gestão de Silveira (1963-1964), seguindo-se aos rápidos governos municipais de Miguel Arraes e Liberato Costa Junior (1960-1962), teve como importante pauta a promulgação e aplicação da Lei Ordinária no 7.427, de 19 de outubro de 1961, a qual dispunha sobre Código de Urbanismo e Obras para a cidade do Recife.

A lei reúne um conjunto de normativas para edificação ou modificações de características de zonas públicas ou privadas da cidade, mas não somente. Ela introduz, no contexto do código urbanístico da cidade de Recife, a gestão da cultura enquanto componente das formas urbanas. Não que as gestões não se debruçassem sobre os temas da cultura e não tratassem especificamente disso, mas vê-se, nesse caso específico, o recurso da cultura como tema circunscrito à gestão urbana. Em nossos 
dias, isso fica bem claro quando, por exemplo, a Diretoria de Preservação do Patrimônio Cultural (DPPC) de Recife é deslocada da gestão da Secretaria de Cultura para a Secretaria de Desenvolvimento Urbano (2015), mas, no início dos anos 1960, isso apenas sinalizava um sofisticado instrumento que seria bastante utilizado sob a gestão nomeada pelo interventor federal pós-1964, a saber, o governo municipal de Augusto Lucena.

Figura 5 - Publicação do Diário de Pernambuco a respeito da querela Prefeitura versus Iphan.

\section{A igreja cai, tradição cede lugar a avenida}

\section{Da Sucursal do RECIFE}

O prefeito Augusto Lucena, do Recife, conseguiu, finalmente, ver executada a obra que já estava constituindo um desafio às suas realizaçōes e que mais esforco e insistencia exiglu desde que cssumiu o governo da cidade: demolir a tradi. clonal Igreja dos Martírios. 0 velho templo, de reconhecido valor artistico - chegou a ser tombedo pelo Institato do $\mathrm{Pa}$. thimonlo Artistico - Histórloo Nacional - cedeu o lugar a avenida Dantas Barreto, cujas ohras estavam paralisadas agora vło prosseguír.

A demoliçäo da Igreja co. megcou ontem às 10 e 30 , e 0 . prefelto festejou-a como se fes: tejam cs grandes acontecimentos. Houve queima do fogos, providenciados pela beata Isaura Barbosa, além de manifestacōes singulares como a do fotógrafo Passos, da Prefeltu. ra, que cortou o cabelo em pleha avenida como pagamento de uma primessa. Faltou apenas uma banda de musica, mas não faltarant os longos discursos. $E$, justamente quando o prefeito iniciou sua oração, na parte interna do templo, teve que Interrompè-la e salr as pressas, junto com a assistência. $\mathrm{E}^{\prime}$ que a Igreja deu a impressão de que ia calr em clma do to. dos.

\section{PREFEITO VENCE}

A luta entre o prefeito $e-0$ Inotituto do Patrimonlo Artis. tico - Fistórico Nacional comegou quando as obras da ave nids Dantas Barreto se aproximaram da Igreja dos Marti. rios e pararam enquanto se providenciava demoliçāo do imovel, como queria o prefeito e negava o instituto.

No dia 10 de agosto de 1971 , um velho predio do n.o $370 \mathrm{da}$ rua Augusta, Já condenado pela Prefeltura, rulu e causou a morte de cinco pessoss e fertmentos em 17. 0 acidente forcou os argumentos contra a permanencia da Igrefa, afirmando o prefeito que ela es. tava prestes a cair. Contudo, uma firma especializada, contratada pelo instituto para vistoriar o imovel, concluiu que nảo havia nenhum perigo.

Pcucos dias depois, ou seja, na noite do dia 20 de agosto, os moradores do bairro de Sảo José viram assustados a torre da Igreja desabar. Com os primeiros sinais do acidente, todos abandonaram o local e nāo houve yitimas. Mas a ocorréncia se transformou em mais um episodio da demanda. Dor gil Fernandes Barbosa, provedor da Irmandade do Bom Jesus dos Martírios, proprietíria do Imovel, culpou o prefelto pela queda da torre, afirmando que fol provocada por serviços executados na área pela Prefeltura, que abalaram os allicerces.

A partir dai, o problema pas. sou asfera federal. Foi apreciado pelo Conselho Federal de Cultura, mereceu um parecer do ministro da Educação e, flnalmente, a 11 de abril de 1972, o presidente Médici inva. lidou 0 tombamento. E 0 prefoito pode festejar, ontem, a demolicão tảo almejada.

Fonte: Arquivo Público de Pernambuco.

Os governos estaduais, durante o regime militar brasileiro, procuraram traduzir bem a cartilha da gestão federal, insistindo, notadamente a partir de 1968, no discurso do "Brasil, ame-o ou deixe-o". Essa narrativa se materializava num Estado de polícia profundo e em um conjunto de intervenções/obras no urbano que deveriam representar a grandeza do Estado, seus traços de uma história vencedora
- tradicional - e, ao mesmo tempo, grande disposição para o desenvolvimento, progresso.

Grandes obras sobre a cidade, portanto, exerceriam de forma ainda mais intensa o papel de dar materialidade a uma cultura do passado-presente enquanto importante dispositivo de gestão. As vozes destoantes do processo não indicariam somente uma má interpretação do mesmo pelo lugar político da oposição, 
mas, bem pior que isso, representariam o lugar de inimigo do Estado. Assim, discordar da retomada e ampliação das demolições para a construção da Avenida Dantas Barreto - ele- mento paradigmático de nosso segundo recorte -, por exemplo, seria o mesmo que ser contra a cidade, sua história e a esperança de seu desenvolvimento.

Figura 6 - Perspectiva da Avenida Dantas Barreto em dias atuais.

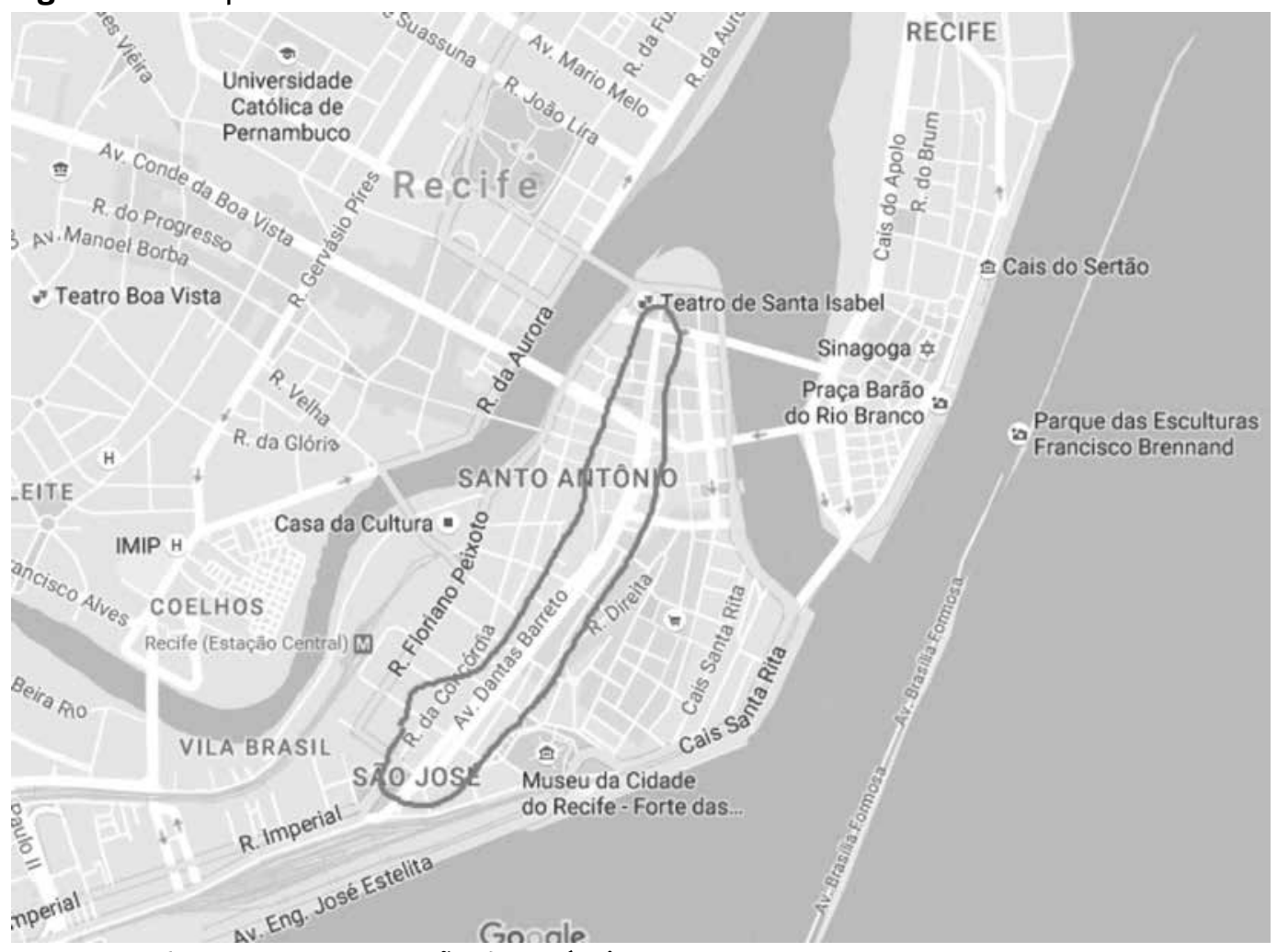

Fonte: Google Maps, com marcação dos próprios autores.

Os protestos contra a demolição da Igreja dos Martírios não foram poucos, mas foi enquanto entrave do crescimento que o Iphan era recorrentemente apresentado pelos discursos oficiais ao longo de debate sobre a demolição, em 1973, para a sequência do conjunto de intervenções para a nova avenida, como podemos observar no texto da Figura 5. Ainda que um sem-número de traçados alternativos para o projeto de avenida desenvolvido na década de 1930 tivesse sido oferecido ao governo municipal, demolir igrejas (Paraíso e Martírios), remover populações, construir viadutos sobre fortes - Viaduto das Cinco Pontas - configurariam exemplos da atuação de um Estado com poderes máximos, reprojetando, inclusive, a relação dos cidadãos com a representação de si mesmos, seus marcadores de identidade/ cultura (perspectiva da Figura 6: Avenida Dantas Barreto em dias atuais). 0 ápice desse movimento foi a suspensão, em abril de 1972, pelo presidente Médici, do tombamento da Igreja dos Martírios, realizado menos de um ano antes. No texto de opinião, publicado no Diário de Pernambuco de 4 de julho de 1971, observamos Gilberto Freyre destacando justamente esse movimento da gestão municipal:

Se eu fosse prefeito do Recife, não me deixaria possuir pelo mesmo ardor quase místico que, mais do que qualquer outro, parece animar atualmente o bom burgomestre Lucena. 0 furor de destruição imediata e maciça do bairro de São José, todo ele a ser crucificado, juntamente com a igreja simbolicamente chamada dos Martírios, é o que Sorel chamava de "mito do progresso". E vou dizer porque: se eu fosse o Prefeito Lucena, sempre bem intencionado, 
porém, por vezes, um tanto desorientado, me dedicaria à Avenida Beira Rio; à reabilitação do desprezado Capibaribe; a uma obra assim, tanto de arrojada modernidade, quanto de essencial equilíbrio ecológico... Valendo-me do saber dos meus assessores, que não seriam apenas engenheiros dominados pelo sentido linear dos empreendimentos urbanos, porém também artistas como Lula Cardoso Ayres, Francisco Brennand, poetas como Mauro Mota e João Cabral, geógrafos como Gilberto Osório e Mário Lacerda, cientistas, sociólogos, humanistas, jornalistas, historiadores, educadores, trataria de cortar as asas da grandiosidade banalmente reta que é a continuação da Avenida Dantas Barreto.

O estranhamento de Freyre, como aquele verificado ainda nos anos 1920, diz respeito ao receio de ver a cidade de seu tempo ser demolida pelo espírito progressista, mas não somente. Refere-se também a um programa de intervenções na cidade que, obviamente, não versam apenas sobre a engenharia de vias e espaços, mas sobre a experiência de vida e consumo coletivos na cidade, sua dinâmica cultural. Freyre denuncia, então, a ausência de profissionais de um campo da cultura/artes na gestão da municipalidade, ainda que isso represente, efetivamente, apenas um tipo específico de participação. A cidade de Freyre estava se desmontando, mas conservando seu poderoso dispositivo sadomasoquista, aquele que o próprio autor já havia identificado na sociedade colonial (Casa-grande \& Senzala) e numa cidade na primeira experiência republicana (Sobrados \& Mucambos): uma república de confraria do poder soberano sobre uma plebe celebrada pela narrativa da grandeza cultural da cidade.

A cereja desse bolo foi a conversão da antiga Casa de Detenção em Casa da Cultura de Pernambuco. Em 1973, o prédio que, desde 1867, abrigava o principal presídio da cidade, foi fechado a fim de que a região central não mais possuísse um equipamento de repressão. Lina Bo Bardi e Jorge Martins Junior assinaram um projeto de adequação do edifício ao propósito elaborado ainda pelo chefe da casa civil do Estado, no governo de Miguel Arraes, a saber, o artista Francisco Brennand, em 1963. Em abril de 1976, a Casa da Cultura de Pernambuco foi reaberta à população, abrigando, até hoje, um importante núcleo do artesanato, ainda que seja, efetivamente, um equipamento pouco cuidado e que atraia pouca atenção dos usuários locais.

A antiga Casa de Detenção era um edifício construído a partir do modelo do panóptico de Bentham; os dois eixos do edifício se cruzavam e nessa intersecção havia uma torre que, facilmente, poderia observar todo o movimento do presídio. A conversão de um modelo desses em casa da cultura, durante o regime militar brasileiro, não deixa de ser paradigmática. Representa, em primeiro lugar, a cultura como recurso político para o tempo, seja para funcionar como mecanismo de compensação para a cidade, seja para traduzir em um dispositivo panóptico um determinado uso da cultura popular. Em segundo lugar, significava ainda uma mensagem para a cidade: modificar a cidade é modificar a cultura urbana, o que materialmente estava configurado na abertura da Casa da Cultura.

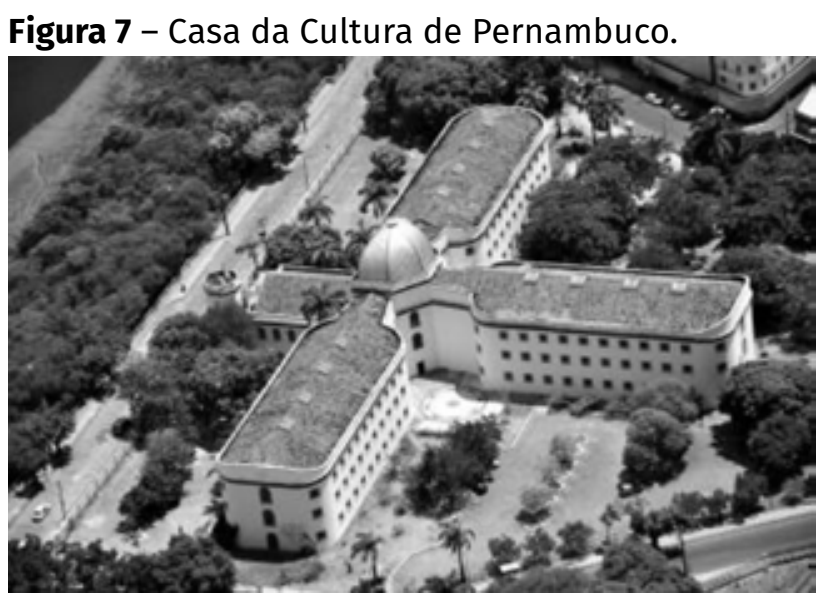

Fonte: Museu da Cidade do Recife.

Se o artigo 876 da lei no 7.427 determinava que a instalação de relógios, estátuas fontes e demais monumentos dependeria do juízo do 
prefeito e da aprovação dos projetos pelo Departamento de Engenharia e Obras, responsável por verificar o valor artístico do conjunto, a construção da Casa da Cultura representa o ponto máximo do juízo do Estado sobre a cultura: objeto material, administrável, a ser celebrado como tradução de uma municipalidade vitoriosa, tradicional, mas, fundamentalmente, orientada para o desenvolvimento, progresso.

Não é nosso desejo, com esta argumentação, discordar do caráter de palimpsesto das cidades. Sim, elas são construídas sobre suas próprias ruínas e sua narrativa também está montada sobre a disposição para se modificar. Não é exagero dizer que a imagem que melhor traduz as últimas décadas do século XX é a transmissão televisiva da população destruindo o "monumento" do Muro de Berlim, num exercício fantástico de profanação de um ícone de um tempo que se buscava superar. Um sem-número de outros exemplos poderia ser apresentado aqui; um deles é nosso terceiro recorte em análise neste trabalho, mas efetivamente não é isso que verificamos no conjunto de intervenções que observamos na Recife dos anos 1930, bem como no urbanismo dos anos 1970.

Os eventos que se materializam - seja na Avenida Guararapes, seja na Avenida Dantas Barreto - não traduzem uma cidade, como um texto (HUYSSEN, 2014), sendo reescrita por sua complexa dinâmica política cotidiana. Não há nesses traços exemplares qualquer espontaneidade da cidade em reinventar seus lugares, modificar sua experiência de habitação a partir dos esforços e interesses dos moradores das localidades (JACOBS, 2014; LEFEBVRE, 2001). Pelo contrário, discutimos a atuação de dispositivos de gestão do urbano como traço mais poderoso que aquele que simplesmente pretende borrar a cartografia da cidade. É um traço impositivo, hegemônico, que escreve a cidade sobre suas próprias ruínas, produzin- do, no entanto, o passado como tempo sempre presente da glória e do desejo do progresso, de uma cultura do passado-presente, nociva às estratégias de vida e consumo coletivos que se descolam da gestão institucional da cidade.

Apesar de intervenções, de reconstruções do tecido urbano, essas, sim, representam um colapso da dimensão palimpsesto da cidade contemporânea, nosso objeto na etapa subsequente deste trabalho.

\section{Gentrificação e resistência}

Birzeit, Cisjordânia - Quando o Museu Palestino de U\$ 24 milhões celebrar sua abertura na próxima quarta-feira, ele terá quase tudo: um impressionante e contemporâneo novo edificio; ambições crescentes para um espaço que projeta celebrar e redefinir arte, história e cultura Palestina; um anfiteatro ao ar livre; um jardim com terraço. Uma coisa que o museu não terá é exposições. (NEW YORK TIMES, 16 de maio de 2016, tradução nossa) ${ }^{4}$

A chamada da matéria que, no último maio, apresentava o Museu Palestino ao mercado do turismo global destaca a principal missão da nova instituição: celebrar e redefinir arte, história e cultura palestina. Um alto investimento em um aparelho cravado em uma já tradicional zona de conflitos nos apresenta a "simpatia" do mundo ocidental ao patrimônio oriental. 0 museu deve rapidamente se converter em grande centro de visitas de turistas de todo globo - mas, fundamentalmente, asiáticos -, contando, para isso, com voos regulares para a região, o que, certamente, produzirá um grande número de empregos diretos para a população local e talvez um incalculável desenvolvimento indireto da região. Por que pôr

4 "BIRZEIT, West Bank - When the \$24 million Palestinian Museum celebrates its opening on Wednesday, it will have almost everything: a stunning, contemporary new building; soaring ambitions as a space to celebrate and redefine Palestinian art, history and culture; an outdoor amphitheater; a terraced garden. One thing the museum will not have is exhibitions". 
em discussão um projeto desse porte? Por que debater um produto cultural que celebra a diversidade cultural e gera desenvolvimento?

Frequentemente, os críticos a esse tipo de equipamento ocupam o dificil lugar de marcar uma oposição a um produto que sustenta o tempo inteiro o desenvolvimento local como sua principal bandeira, atrelada, por sua vez, à valorização da memória/patrimônio do lugar. Se, ao longo dos anos 1980 e, intensamente, durante os anos 1990, grandes cidades do Brasil desenvolveram seus programas para requalificação urbana, seguindo tendências europeias, parece claro que os equipamentos de cultura introduziram um componente a mais na questão em debate. Antigos bairros operários em cidades como Londres ou Manchester, regiões portuárias em Lisboa ou Buenos Aires, antigas zonas de conflito, baixo meretrício e total abandono em Salvador ou Recife figuram alguns dos exemplos já bastante estudados a respeito de complexos programas de intervenção, higienização e reprogramação de zonas urbanas inteiras em antigos enclaves urbanos. Em todos os casos, as narrativas sobre a valorização da cultura local e da história do lugar (bairro, cidade ou país) estavam ao centro das maquetes que se materializaram em zonas de um tipo complexo de vazio: o vazio do "novo" turismo cultural (JEUDY, 2005; SANTOS e PEIXOTO, 2013; YÚDICE, 2004).

Esse movimento, por certo, notadamente a partir dos anos 2000, tem ganhado o importante reforço de um boom de museus associado a processos de gentrificação. Mesmo em cidades do dito antigo Terceiro Mundo, há estudos demonstrando a importância dos equipamentos museológicos como meios de massas para uma nova representação da diferença, como pode, por exemplo, ser observado no trabalho de Appadurai e Breckencridge e na crítica possível a ele (SÁ BARRETO, 2014). Esse entusias- mo, contudo, sinaliza uma perda de fôlego à medida que esses produtos culturais têm sido cada vez mais associados a ainda mais sofisticados empreendimentos de exclusão e, eventualmente, apenas ligados a dispositivos para uma nova fase do mercado imobiliário e sua intensa especulação.

Dessa maneira, regiões de centro ou bairros inteiros foram (re)construídos para darem vasão a uma mercadoria da cultura renovada e extremamente lucrativa. Trata-se da própria cidade - ou zonas inteiras delas - como produto, tal qual mais recentemente pudemos observar com mais familiaridade devido à realização de Copa do Mundo e Olimpíadas no Brasil. A já vasta produção sobre os impactos dos grandes eventos para as cidades brasileiras é apenas um indicativo do movimento. Nesses casos, é quase sempre presente uma narrativa do desenvolvimento como estruturante de discursos para "novas" cidades, mais limpas, bonitas e modernas que as cidades anteriores. Os megaeventos produziram isso não somente no Brasil. É possível observar esses efeitos nas cidades portuguesas pós-Euro2004 (FORTUNA \& PROENÇA LEITE, 2009) ou mesmo na já longínqua Barcelona, pós-1992.

Um exercício mais cuidadoso, no entanto, pretende observar esse movimento independente dos megaeventos e é ligado a um processo tido como "natural" para as grandes cidades do globo, além de necessário às novas políticas para desenvolvimento urbano. É esse o sentido, por exemplo, para as intervenções na antiga região portuária e bairro operário de Buenos Aires (MONTALDO, 2010; SARLO, 2005). 0 grande número de brasileiros na capital argentina ao longo da última década, fruto provável de um câmbio e momento econômico bastante favoráveis, logo converteu o novo bairro de Puerto Madero em objeto de desejo nas falas "desinteressadas" da classe média endinheirada em cidades como Recife. 0 processo de 
requalificação urbana dos anos 1990 não seria mais suficiente.

Ao longo daqueles anos, houve grandes investimentos das gestões municipais de Jarbas Vasconcelos e Roberto Magalhães (1993-2000) no que poderia ser chamado de uma "reconstrução" do bairro do Recife. Vias tiveram seu calçamento original recuperado, as populações em situações de rua foram deslocadas exceto o enclave da Comunidade do Pilar, problema para esse tipo de gestão municipal até os dias de hoje -, um novo colorido das ruas deu lugar ao tom ocre da virada do século anterior e alguns equipamentos de cultura foram estimulados a funcionar na região (PROENÇA LEITE, 2007). O caso mais evidente desses produtos é o da Sinagoga Kahl Zur Israel, na Rua do Bom Jesus, reaberta como museu/memorial nos anos 1990, depois de escavações arqueológicas, para exposição de antigos artefatos. Rapidamente, a rua tornou-se região bastante frequentada por turistas e classe média local, com bares e alguns festivais musicais ou feiras temáticas. Além disso, as gestões investiram no desenvolvimento do potencial empresarial na região, concentrando um bom número de empresas de tecnologia da informação em torno do que passou a se chamar Porto Digital.

As políticas, contudo, não foram suficientes para reconstruir uma vocação residencial para o bairro - efetivamente esse não era o projeto na época - e não houve produtos para as populações pobres que já habitavam a região. Pelo contrário, sobre elas recaiu ainda maior invisibilidade, o que reforça o caráter de gentrificação sobre todo o conceito para o "novo" Bairro do Recife (PROENÇA LEITE, 2007). Além disso, uma nova circulação para aquelas ruas concentrou-se exclusivamente no consumo de entretenimento, permanecendo a região esvaziada durante boa parte da semana e dos horários. Os "usuários" diários dos bairros ficaram basicamente restritos aos empregados das empresas de tecnologia, funcionários de um jornal de média circulação na cidade, e servidores públicos - visto que a sede da prefeitura do Recife fica no bairro. No final dos anos 1990, era possivel concluir que as gestões preferiam ruas vazias e belas a um tipo "pobre" de uso da região.

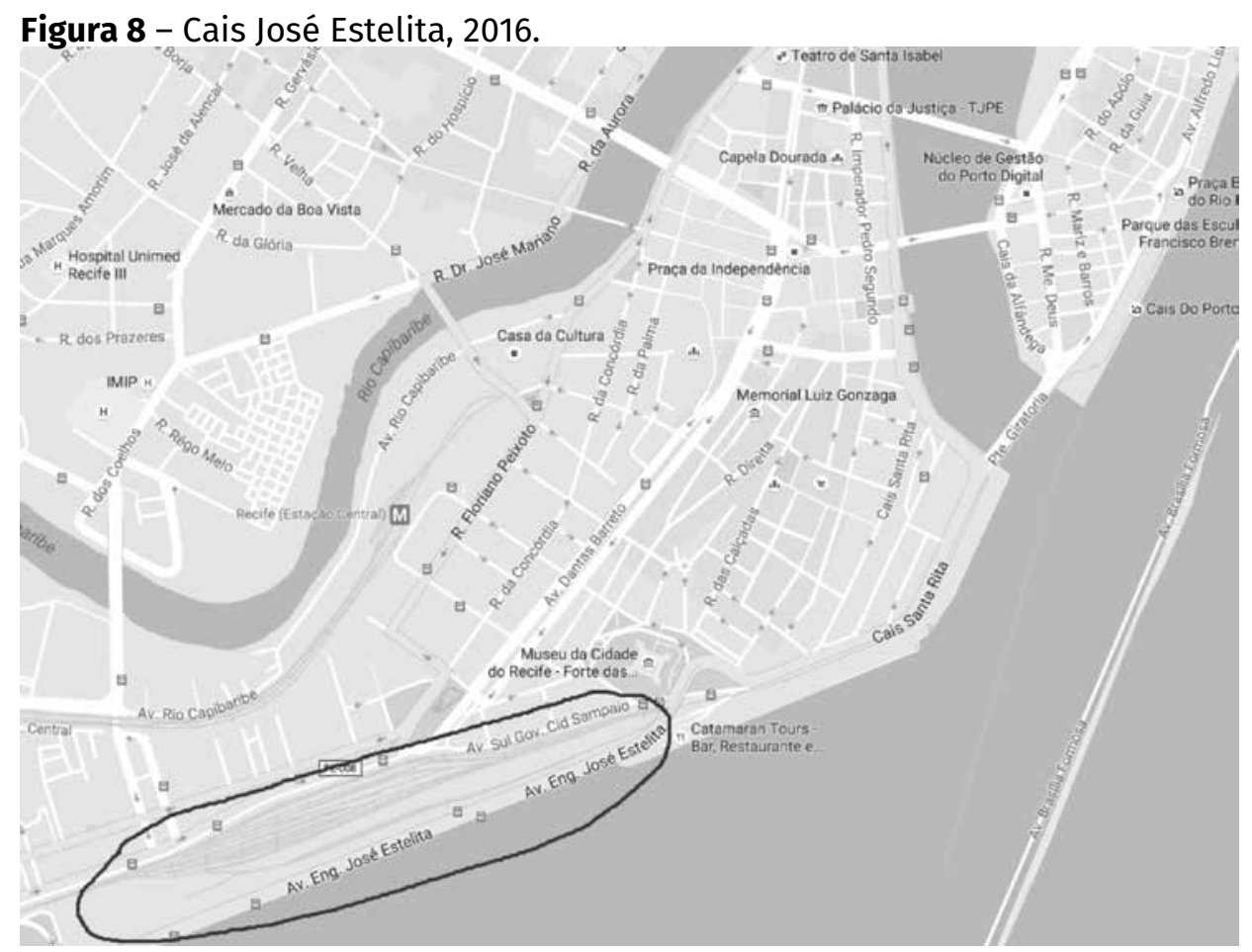

Fonte: Google Maps, com marcação dos próprios autores. 
A gestão de João Paulo (2001-2008) deu menos atenção ao processo de gentrificação das ruas que já estavam sendo exploradas, concentrando seus discursos da ideia de administração popular fortemente marcada pelo multiculturalismo. Investiu grandes esforços na descentralização do Carnaval do Recife, iniciativa que teve produtos ao mesmo tempo interessantes e perversos. Recuperou o tom de "prefeito de obras sociais" em voga durante o mandato de Pelópidas Silveira, sendo responsável por importante política de contenção de desabamentos nos morros da cidade, mas protagonizou, contudo, uma péssima condução das políticas de gestão urbana e seu código de obras, não controlando um desenfreado processo de verticalização - vinculado à forte especulação imobiliária - e, por fim, sendo a gestão responsável pelo leilão - até hoje sob suspeita - do antigo terreno da RFFSA, que ficaria mais conhecido como "caso Estelita". Em 2007, um primeiro projeto para a região dos antigos galpões apareceu nos cadernos de Cultura dos grandes jornais em circulação em Recife, demonstrando o complexo cruzamento entre gentrificação, cultura e especulação imobiliária, como podemos observar no editorial do Jornal do Commercio de 6 de abril de 2012:

Seguindo os exemplos de outras grandes cidades do mundo - como Barcelona, Buenos Aires, Roterdã, Cidade do Cabo - o Rio de Janeiro está dando andamento ao projeto Porto MaraviIha, com que se busca a revitalização da área onde está localizado o seu centenário porto, onde vivem 22 mil pessoas com um dos menores índices de desenvolvimento urbano da cidade. A conclusão do processo de transformação da área - devendo abrigar uma população de 100 mil pessoas - está prevista para 2015. 0 entendimento é de que o Porto Maravilha é necessário para a inserção de uma área de cinco milhões de metros quadrados no planejamento da cidade. 0 que isso tem a ver com o Recife ficou bastante visivel na apresentação do projeto de reocupação dos antigos armazéns do
Cais José Estelita, no Centro do Recife, uma área praticamente abandonada, servindo de abrigo a uma população favelada. 0 propósito é construir 12 prédios, criação de praças, ciclovias, bares, restaurantes, quiosques, pista de cooper, abertura e criação de ruas para diminuir o impacto do trânsito na área. Como no Rio e todos os grandes centros urbanos que revitalizaram seus portos, o projeto do Recife tem um caráter estruturador para qualquer plano urbano que se queira fazer para a cidade.

Como podemos observar com facilidade, nos discursos de promoção do Projeto Novo Recife, não há cidade possivel fora do desenvolvimento cultural estruturado pela lógica da gentrificação. Mais do que uma ideia, a partir da valoração do pobre como objeto de repulsa - exceto nos bem administrados círculos dos equipamentos culturais -, a requalificação urbana que o projeto propõe se apresenta enquanto alternativa única para uma cidade - ainda que tomada somente a partir daquela região -, afastando-se de uma tradição de pioneirismo e grandiosidade. É nesse tom que segue o editorial:

Não viram que a cidade precisa ser repensada e isso exige grandes empreendimentos, como esse que é oferecido para o Cais José Estelita, com repercussão imediata no mercado de trabalho, na qualidade de vida para muitas pessoas que terão oportunidade de se beneficiar com os equipamentos sociais ali instalados, e para toda a cidade, pelo processo de renovação do que está degradado. Não se trata de se interferir em espaços históricos ou deformar algum caráter cultural específico da cidade. Trata-se, sim, de dar a um espaço degradado a possibilidade de inserção em um grande plano urbanístico, para o qual - aí sim - se deveriam voltar todas as atenções, inclusive desses grupos que se colocam contra o projeto do Cais. Honestamente, não dá para entender essa posição contrária à melhoria do Centro da cidade do Recife (Jornal do Commercio, 6/4/2012).

A série de fotos abaixo apresenta uma sequência de perspectivas do Cais José Estelita e a "interferência" do Projeto Novo Recife. 
Figura 9 - Cais José Estelita.

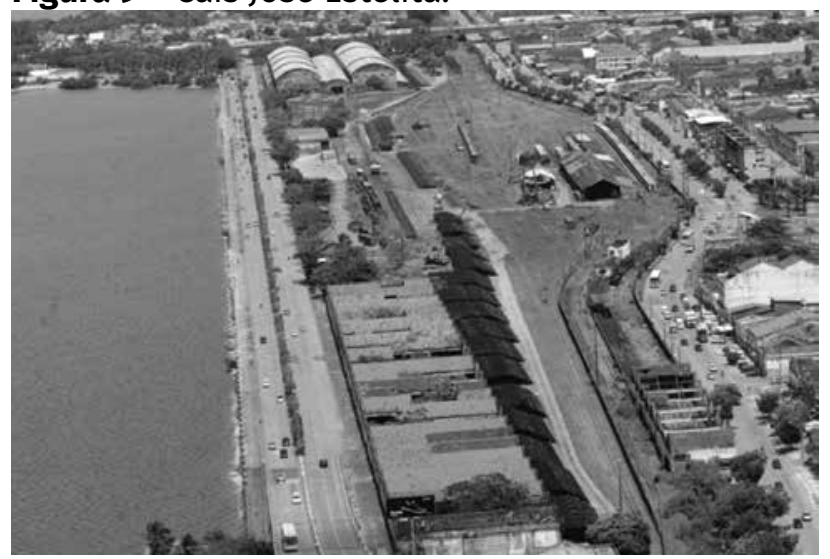

Fonte: Museu da Cidade do Recife.
Figura 10 - Perspectiva do Projeto Novo Recife.

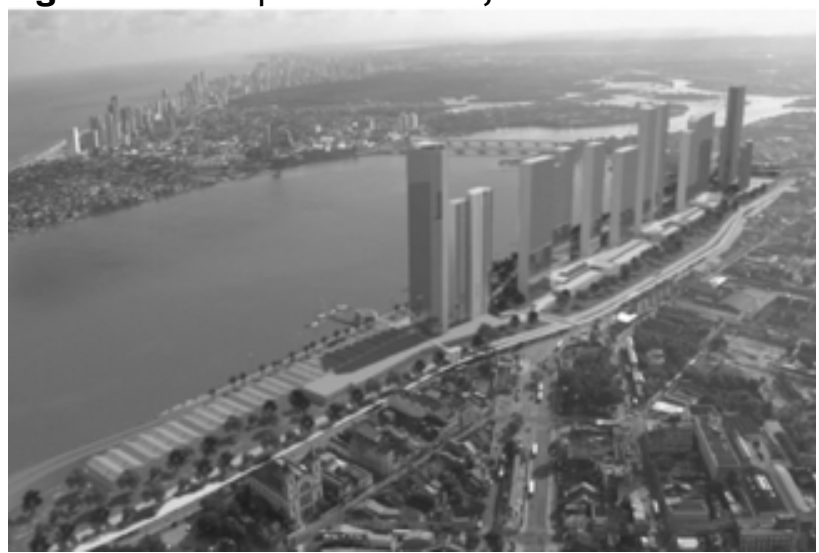

Fonte: Site do Projeto Novo Recife.

Figura 11 - Cais José Estelita, perspectiva a partir de Brasília Teimosa.

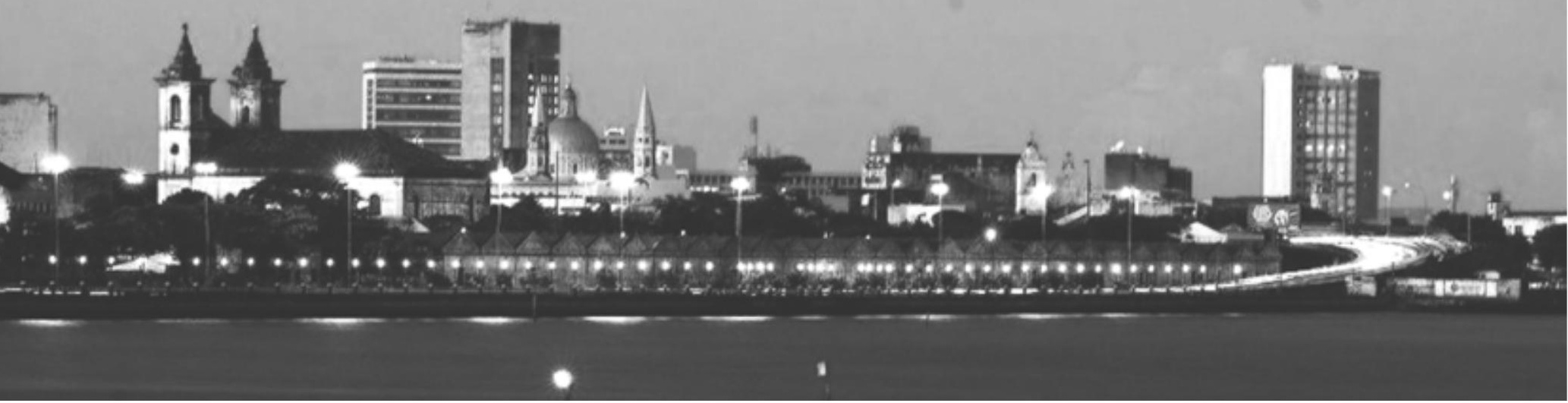

Fonte: Museu da Cidade do Recife.

A Figura 10 representa uma projeção da região da cidade após a construção das 12 torres. 0 primeiro elemento a ser observado, em comparação com a Figura 11, é a enorme disparidade de gabarito entre as torres e as demais edificações da região. Somente esse dado já é suficiente para colocar em debate o conjunto de construções como grande interferência na paisagem cultural da região (VERAS, 2014). Ciente de que também a paisagem atual é resultado de um conjunto de outras intervenções (dimensão palimpsesto), eventualmente violentas como as que verificamos nos anos 1940 ou 1970, investimos na tese de que a ruptura da paisagem aprofunda ainda mais a disposição para a exclusão tão evidente nas "reconstruções" da cidade. Como em outras grandes cidades, os enclaves fortificados con- verteram-se em zonas protourbanas dentro de tradicionais cidades, marcando com o isolamento formas urbanas contemporâneas (RIO CALDEIRA, 2000). Em Recife, não podemos mais simplesmente falar em grandes edificios com muros que chegam aos dez metros de altura, mas de novos bairros inteiros construídos para uma "outra experiência de cidade". É o caso da região do Paiva - uma praia cujo acesso é dificultado por uma rodovia com pedágios - e de condomínios de edifícios que se lançaram no desafio de simular completamente a experiência urbana: Evolution shopping park ou Le Park residencial.

A interferência, portanto, diz respeito à rasura sobre a paisagem política da cidade, aquela que produzimos a partir das estratégias para atuar sobre modos de vida e consu- 
mo coletivos cotidianamente, dinâmica que se reproduz não sem desigualdades por meio do uso diário dos lugares da cidade. O Projeto Novo Recife, montado sobre o discurso do desenvolvimento e de preservação de características de uma cidade forte e pioneira, não oferece mais do que sofisticação das políticas de interdição, em um movimento ainda mais sofisticado do que aquele a que assistimos durante o empreendimento de gentrificação dos anos 1990. Ademais, tem contado com grande apoio da gestão municipal de Geraldo Júlio (2013-2016) que, como Novais Filho, coordena de perto a atuação de uma equipe técnica comprometida com um projeto de cidade intensamente excludente. Não por acaso, a figura pública do prefeito tem sido o principal alvo das muitas produções das resistências ao desenvolvimento do projeto.

No dia 10 de fevereiro de 2012, em meio a uma semana de manifestações contra o aumento das passagens de ônibus e pela melhoria do transporte público - mobilizações quase sempre predominantemente estudantis -, o Diario de Pernambuco publicou em sua matéria de capa a manchete 'A cidade não aguenta mais isso'. A reportagem pretendia explorar o quão insuportável a vida em Recife (capital do Estado) se transformava todas as vezes em que as manifestações que se estendiam por aquela semana se realizavam. As fotos apresentadas na matéria apresentam vias congestionadas e o bloqueio recorrentemente realizado pelos manifestantes. É bem nítido, no texto em questão, o esforço para criminalização das resistências, identificando nelas um risco aparente de um 'sobre tudo reclamar' que em muito parece incomodar o projeto moderno de cidade e vida para o consumo. (BENZAQUEN \& SÁ BARRETO, 2013, p. 15)

Nas cidades acometidas por essa nova forma de gentrificação, não tem sido dificil verificar um sem-número de estratégias de resis- tência. Como dissemos ainda no início deste trabalho, as formas contemporâneas do nacional estiveram materializadas na luta pela cidade de maneira expressiva nos últimos 20 anos. Os movimentos de rua se traduziram em séries de manifestações pelo Brasil em 2013, quando o uso dos espaços públicos de tornou palco para manifestações de dupla face que, de um lado, flertavam perigosamente com um discurso ufanista e em grande desuso, e, de outro lado, representavam um esforço para profanação de uma esfera política excessivamente institucionalizada e partidarizada (BENZAQUEN \& SÁ BARRETO, 2013).

Em Recife, essas manifestações inspiradas pelos movimentos Occupy foram apenas o início de um conjunto de diversas manifestações. As iniciativas destacaram a necessidade de se pensar outras formas políticas de associação nas cidades contemporâneas, eventualmente chamadas de Novíssimos Movimentos Sociais (NMSs) - por se desprenderem da tradicional luta de classes como seu objeto estruturante (SANTOS, 2005). A ocupação de zonas interditadas pelas lógicas do esvaziamento urbano representou o elemento simbólico desses esforços de associação que, em Recife, são bem representados pelo difuso movimento do Ocupe Estelita.

Não por acaso, os primeiros produtos das resistências insistiram na crítica ao desenvolvimentismo como elemento fundamental do projeto de cidade contemporânea. Não abriram mão, contudo, de uma narrativa da tradição - "cidade de lutas", "história de guerreiros", "memória de resistência", "tradição cultural", "identidade revolucionária" - como importante elemento na composição de seu discurso. Dessa forma, grupos associados ao difuso movimento, formados a partir de matrizes diversas, ofereceram produtos também intensamente diversos como alternativas de uso para o espaço em debate. De equipamentos 
culturais (parques, museus, memoriais, cinemas) até "conservar" o vazio como linguagem de uso da cidade, uma miríade de alternativas, por si só, representaria a profusão de teias que produzem o tecido urbano de cosmopolitas cidades contemporâneas.

Em 2014, quando da eminente demolição dos antigos armazéns no terreno, um grande

Figura 12 - Ocupe Estelita.

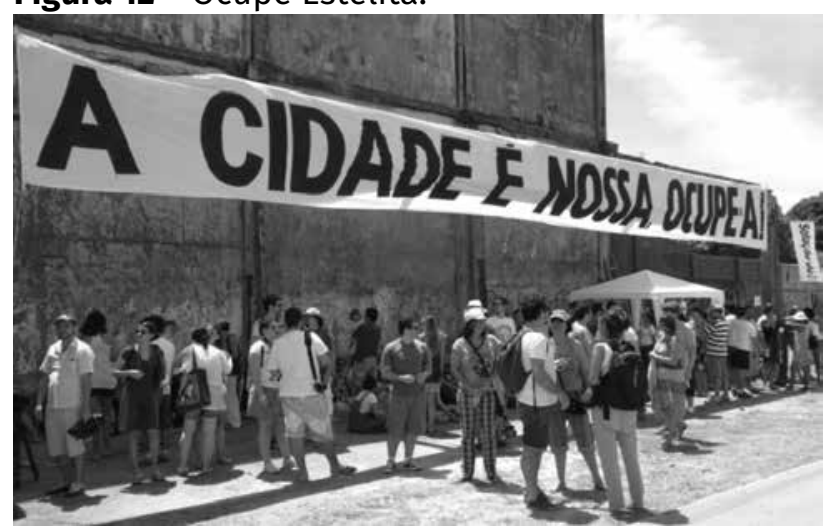

Fonte: Movimento Ocupe Estelita.

Figura 14 - Exemplo de grafismos.

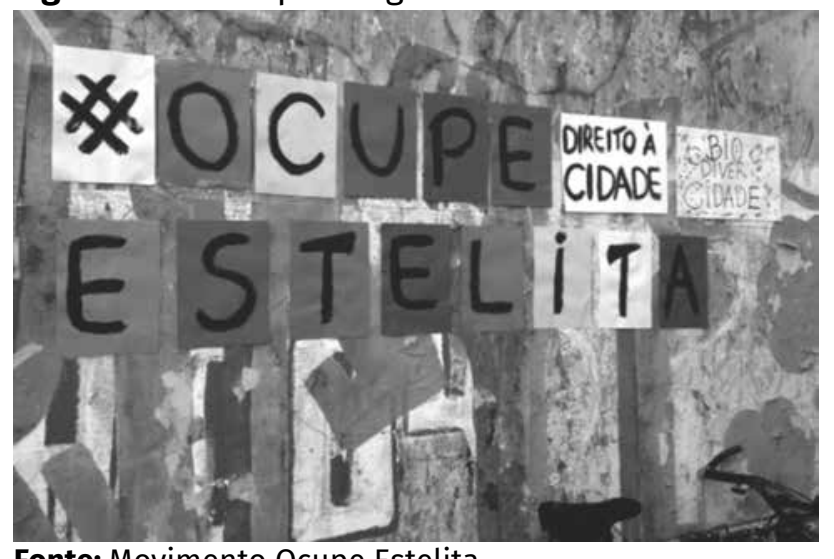

Fonte: Movimento Ocupe Estelita.

Figura 16 - Shows na segunda fase do acampamento.

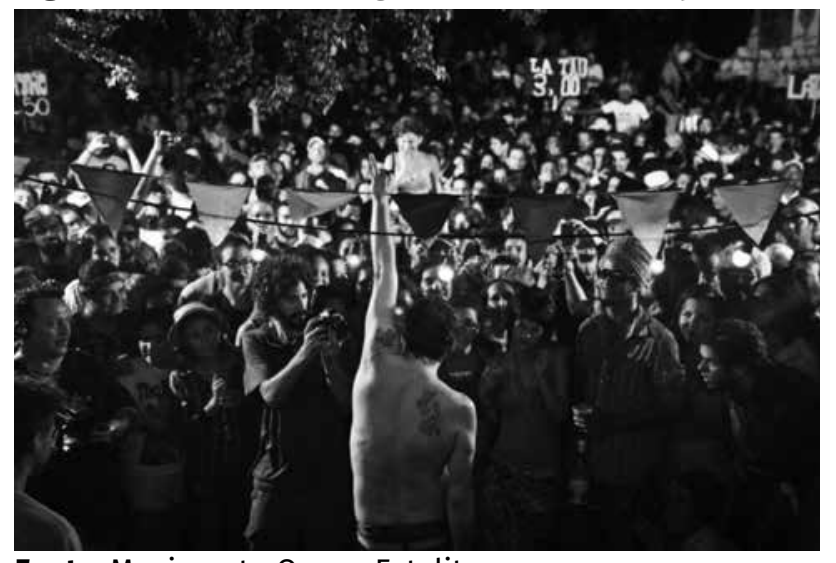

Fonte: Movimento Ocupe Estelita. acampamento foi montado sem uma diretiva muito clara, mas com um objeto em comum: o imperativo de uso da cidade como pedra fundamental para frear projetos pautados em sofisticadas lógicas de interdição. A sequência de imagens abaixo traduz esse esforço difuso de profanação das zonas interditadas da cidade contemporânea:

Figura 13 - Adesão de pescadores.

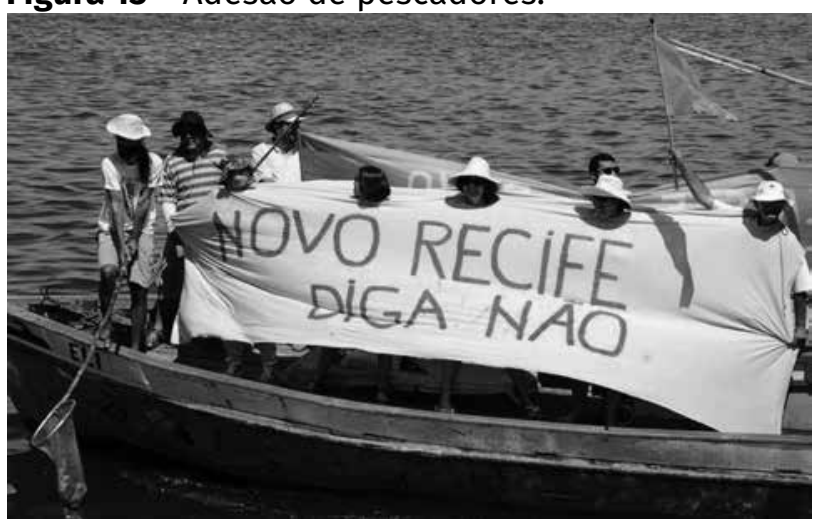

Fonte: Movimento Ocupe Estelita.

Figura 15 - Perspectiva do acampamento.

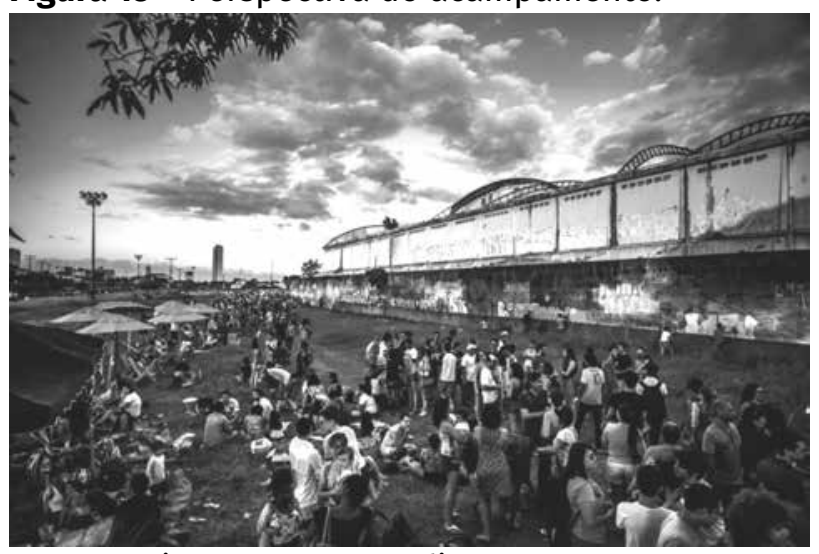

Fonte: Movimento Ocupe Estelita.

Figura 17 - Provocações.

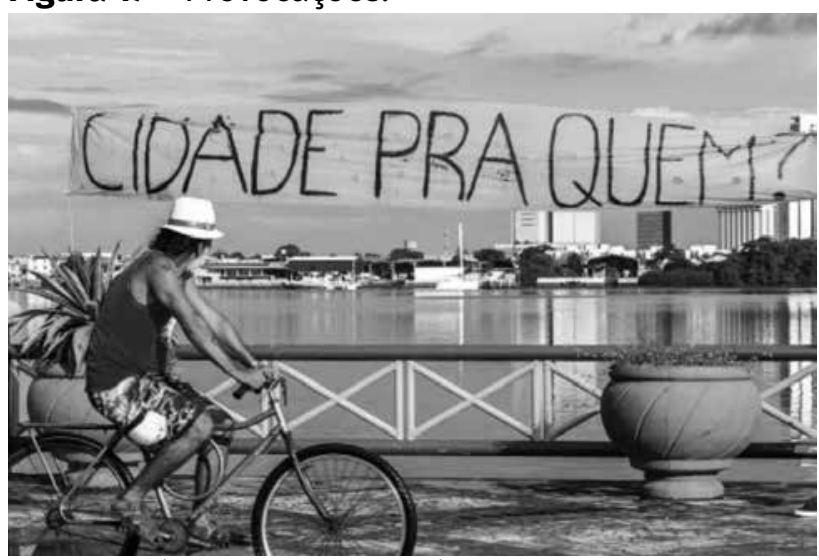

Fonte: Movimento Ocupe Estelita. 
Figura 18 - Aula pública.

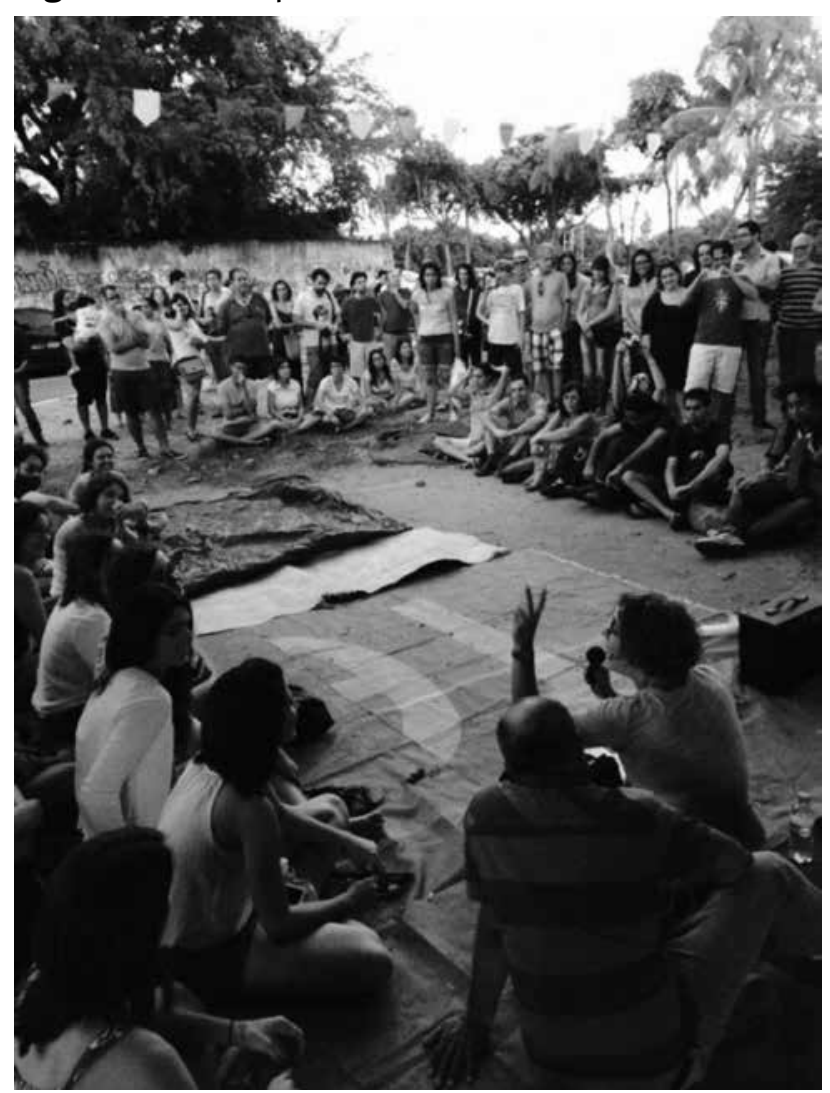

Fonte: Movimento Ocupe Estelita.

O acampamento foi montado no dia 21 de maio de 2014, tendo sido violentamente destruído por força policial durante o jogo da seleção brasileira contra o México, pela Copa do Mundo em 17 de junho de 2014. O movimento montou novo acampamento, dessa vez sob o Viaduto Capitão Temudo, na Praça Abelardo Rijo - sítio, inclusive, esvaziado pela impossibilidade de se chegar a pé e sem vagas de estacionamento -, onde permaneceu até o dia 11 de julho daquele ano, totalizando 50 dias de ocupação ininterruptos.

O legado do difuso movimento, no entanto, se estende a um sem-número de grupos que, organizados, ainda impedem o início das obras do projeto. 0 grupo de Direitos Urbanos, por exemplo, no Facebook, agrega mais de $30 \mathrm{mil}$ membros interessados na temática. 0 conjunto das resistências resumido pelo Ocupe Estelita põe em xeque um tipo exaurido de representação da vida política na cidade, bem como o modelo de racionalidade que a institui.
Figura 19 - Um mês de acampamento.

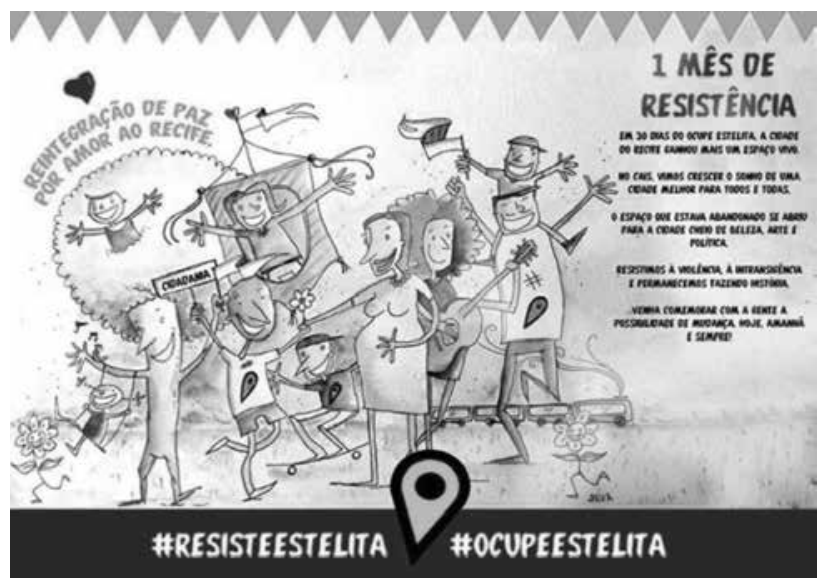

Fonte: Movimento Ocupe Estelita.

A reivindicação de Boaventura de Sousa Santos (2005) pela expansão de uma esfera do presente para que se dê conta de uma experiência ampliada de contemporaneidade parece despontar, nesse cenário, como mecanismo emergente de resistência política contra uma cultura do passado-presente, a partir da qual o futurismo desenvolvimentista e a narrativa nostálgica comprimem as zonas de atuação política do tempo presente. Contra a indolência desse programa de razão para a cidade, os movimentos, ainda pouco estudados, mas já suficientemente evidentes, sinalizam urgências políticas para projetos de cidades que atendam a uma experiência de vida coletiva pouco compativel com as formas gentrificadas do adesionismo cultural pós-45. Estimular a discussão sobre essas formas políticas do contemporâneo, contudo, é um exercício que este trabalho se propôs apenas iniciar.

\section{Referências}

BENZAQUEN, Júlia Figueiredo; SÁ BARRETO, Francisco. A mão dupla da rua: a ambivalência da "nova resistência" ou elementos para uma outra gramática da mobilização. Revista Estudos de Sociologia, Recife, PPGS-UFPE, v. 2, n. 19, p. 1-22, 2013. Disponivel em: https://periodicos.ufpe.br/revistas/revsocio/ article/view/235572/28530 Acesso em: 15 nov. 2019.

Brasil / Recife. Código de Urbanismo e Obras. Diário 
Oficial do Município, Recife, no 7427, 19 de outubro. 1961. Capítulo II, Disposições finais.

DEL CASTILLO, Sonia Salcedo. Cenário da Arquitetura da Arte: montagens e espaços de exposições. São Paulo: Martins, 2008.

Editorial. Jornal do Commercio, Recife, Caderno de cultura, 6 de abril. 2012.

FORTUNA, Carlos; PROENÇA LEITE, Rogério. Plural de cidade: novos léxicos urbanos. Coimbra: Almedina, 2009.

FREYRE, Gilberto. Diário de Pernambuco, Recife, 20 de abril. 1924.

Diário de Pernambuco, Recife, 4 de julho. 1971.

Sobrados e mucambos. São Paulo: Global editora, [1936] 2003.

Casa-Grande \& Senzala. São Paulo: Global Editora, [1933] 2006.

HALL, Stuart. Da Diáspora: identidades e mediações culturais. Belo Horizonte: Editora UFMG, 2003.

HUYSSEN, Andreas. Seduzidos pela memória: arquitetura, monumentos, mídia. Rio de Janeiro: Aeroplano, 2000.

En busca del futuro perdido: cultura y memoria en tiempos de globalización. Buenos Aires: Fondo de Cultura Económica de Argentina, 2001.

Culturas do passado-presente: modernismos, artes visuais, políticas da memória. Rio de Janeiro: Contraponto: Museu de Arte do Rio, 2014.

JACOBS, Jane. Morte e vida de grandes cidades. São Paulo: Martins Fontes, 2014.

JEUDY, Henri-Pierre. Espelho das cidades. Rio de Janeiro: Casa da Palavra, 2005.

LEFEBVRE, Henri. 0 direito à cidade. São Paulo: Centauro, 2001.

MAGALHÃES, Agamenon. Folha da Manhã, Recife, 31 de agosto. 1938.

MONTALDO, Graciela. Zonas ciegas: populismos y experimentos culturales em Argentina. Buenos Aires: Fondo de Cultura Económica, 2010.

New York Times, Nova Iorque, 16 de maio. 2016

NOVAIS FILHO, Antônio de. Folha da Manhã, Recife, 31 de agosto. 1939.

PEIXOTO, Paulo. A identidade como recurso metonímico dos processos de patrimonialização. Revista Critica de Ciências Sociais, Lisboa, CES, n. 70, p. 183204, Dez. 2004. Disponível em: https://estudogeral. sib.uc.pt/handle/10316/10900?locale=pt Acesso em: 15 nov. 2019.

SANTOS, Myrian Sepúlveda dos; PEIXOTO, Paulo. Patrimónios mundiais: fragmentação e mercantilização da cultura. In: PONTES, Geraldo; SANTOS, Myrian Sepúlveda dos; Souza, Rogério Ferreira de; PEREIRA, Victor Hugo Adler (org.). Cultura, memória e poder: diálogos interdisciplinares. Rio de Janeiro: EdUERJ. p. 47-67.

PONTUAL, Virgínia. Uma cidade e dois prefeitos: narrativas do Recife das décadas de 1930 a 1950. Recife: EdUFPE, 2001.

PROENÇA LEITE, Rogério. Contra-usos da cidade: lugares e espaço público na experiência urbana contemporânea. Campinas: Unicamp, 2007.

RIO CALDEIRA, Teresa Pires do. Cidade de muros: crime, segregação e cidadania em São Paulo. São Paulo: Ed. 34, 2000.

SÁ BARRETO, Francisco. A dor e a delícia de ser o que: a brasilidade e o caso do pertencimento como disciplina. 2012, 293 f. Tese (Doutorado em Sociologia) - Programa de Pós-Graduação em Sociologia, Universidade Federal da Paraíba, João Pessoa. 2012.

Por uma experiência da intersubjetividade Museal: elementos para uma agenda de Comunicação e Museus. Revista Musas IBRAM, Rio de Janeiro, IBRAM, Ano VII, no 6, p. 8-27, 2014. Disponível em: http:// www.arquivonacional.gov.br/images/pdf/ musas.pdf.pdf Acesso em: 15 nov. 2019.

SANTOS, Boaventura de Sousa. Pela mão de Alice: o social e o político na pós-modernidade. São Paulo: Cortez, 2005. 
SARLO, Beatriz. Tempo presente: notas sobre a mudança de uma cultura. Rio de Janeiro: José Olympo, 2005.

SEVCENKO, Nicolau. A revolta da vacina: mentes insanas em corpos rebeldes. São Paulo: Cosac Naify, 2010.

SOUZA, Jessé. A invisibilidade da desigualdade brasileira. Belo Horizonte: Ed. UFMG, 2006.

VERAS, Lúcia Maria de Siqueira Cavalcanti. Paisagem-postal: a imagem e a palavra na compreensão de um Recife urbano. 2014. p. 467. Tese (Doutorado em Desenvolvimento Urbano) - Programa de PósGraduação em Desenvolvimento urbano, Universidade Federal de Pernambuco, Recife, 2014.
WACQUANT, Loïc. As duas faces do gueto. São Paulo: Boitempo, 2008.

YÚDICE, George. A Conveniência da Cultura: usos da cultura na era global. Belo Horizonte: EdUFMG, 2004.

ŽIŽEK, Slavoj. Multiculturalismo, ou a lógica cultural do capitalismo multinacional. In: ŽlŽEK, Slavoj et al. Žižek crítico: política e psicanálise na era do multiculturalismo. São Paulo: Hacker Editores, 2005. p. 11-22.

Recebido em: 21.12.2019 Aprovado em: 29.05 .2020 Revisado em: 03.06.2020

Francisco Sá Barreto é doutor em Sociologia, professor adjunto IV do Departamento de Antropologia e Museologia da Universidade Federal de Pernambuco (UFPE), pesquisador do Grupo Curupiras: Colonialidades e Outras Epistemologias (www.curupiras.com), atualmente, coordena pesquisa financiada pela Fundação de Amparo à Ciência e Tecnologia do Estado de Pernambuco (Facepe) acerca do tema Cidades e cultura política. E-mail: xicosabarreto@gmail.com

Izabella Medeiros é doutora em Sociologia, professora temporária do Departamento de Sociologia da Universidade Federal de Pernambuco (UFPE), pesquisadora do Grupo Curupiras: Colonialidades e Outras Epistemologias (www.curupiras.com).E-mail: bellamedeiros@gmail.com 